\title{
Chapter 27 \\ South Africa as a Donor of Alien Animals
}

\author{
John Measey (1), Tamara B. Robinson (1), Natasha Kruger (1), \\ Tsungai A. Zengeya $\mathbb{B}$, and Brett P. Hurley
}

\begin{abstract}
This review provides the first assessment of animal species that are native to South Africa and invasive elsewhere in the world. While around a twelfth of all naturalised plants in the world are native to South Africa, there are very few examples of South African native marine, terrestrial, or freshwater animals becoming invasive elsewhere. We provide a narrative of each of the 34 cases that we could find. Three of these species, the Common Waxbill, Estrilda astrild, the Mozambique Tilapia, Oreochromis mossambicus and the African Clawed Frog, Xenopus laevis, were widely traded, and introduced on several continents with invasive populations becoming the subject of substantial research. Most other species are poorly documented in the literature such that it is often not known whether South African populations are the source of invasions. These species demonstrate the same trend in pathways of animals entering South Africa, moving from deliberate to accidental through time. The role of mavericks, individuals whose deliberate actions wilfully facilitate invasions, is highlighted. While South Africa has acted as an important bridgehead for the invasions of forestry pests, crayfish, fish and amphibians on the continent, it is clearly not a major donor of animal invasions, but rather a recipient. This could be due to South African ecosystems being fundamentally more invasible, or South African fauna showing reduced invasiveness, though it is likely that substantial differences in historical pathways also played a crucial role.
\end{abstract}

J. Measey $(\bowtie) \cdot$ T. B. Robinson $\cdot$ N. Kruger

Centre for Invasion Biology, Department of Botany and Zoology, Stellenbosch University,

Stellenbosch, South Africa

e-mail: jmeasey@sun.ac.za

T. A. Zengeya

South African National Biodiversity Institute, Kirstenbosch Research Centre, Cape Town, South Africa

Centre for Invasion Biology, Department of Zoology and Entomology, University of Pretoria, Pretoria, South Africa

B. P. Hurley

Forestry and Agricultural Biotechnology Institute, Department of Zoology and Entomology,

University of Pretoria, Pretoria, South Africa

B. W. van Wilgen et al. (eds.), Biological Invasions in South Africa, Invading

Nature - Springer Series in Invasion Ecology 14,

https://doi.org/10.1007/978-3-030-32394-3_27 


\subsection{Introduction}

Some animals from South Africa are well known invasives around the world. They have been the subject of numerous studies, and are among the best known invaders of their taxa. For example, the African Clawed Frog, Xenopus laevis, is the third most studied invading amphibian (van Wilgen et al. 2018), and the Mozambique Tilapia, Oreochromis mossambicus, has been heralded as one of the most widely introduced fish species globally (Pullin et al. 1997; Froese and Pauly 2019, Fig. 27.1). However, there seem to be few examples and, to our knowledge, there has been no attempt to compile a comprehensive list of fauna donated from South Africa, which are established elsewhere in the world. Thus, our aim in this chapter is to compile such a list, and determine the mode and tempo of these introductions. In addition, we attempt to document the pertinent literature providing a brief overview of the native and invasive distribution, the pathway, and impacts of each species.

One of the ways in which South Africa is a donor of alien animals is by the bridgehead effect. This is where alien species introduced to South Africa have become established, and South Africa has subsequently become a source of invasion

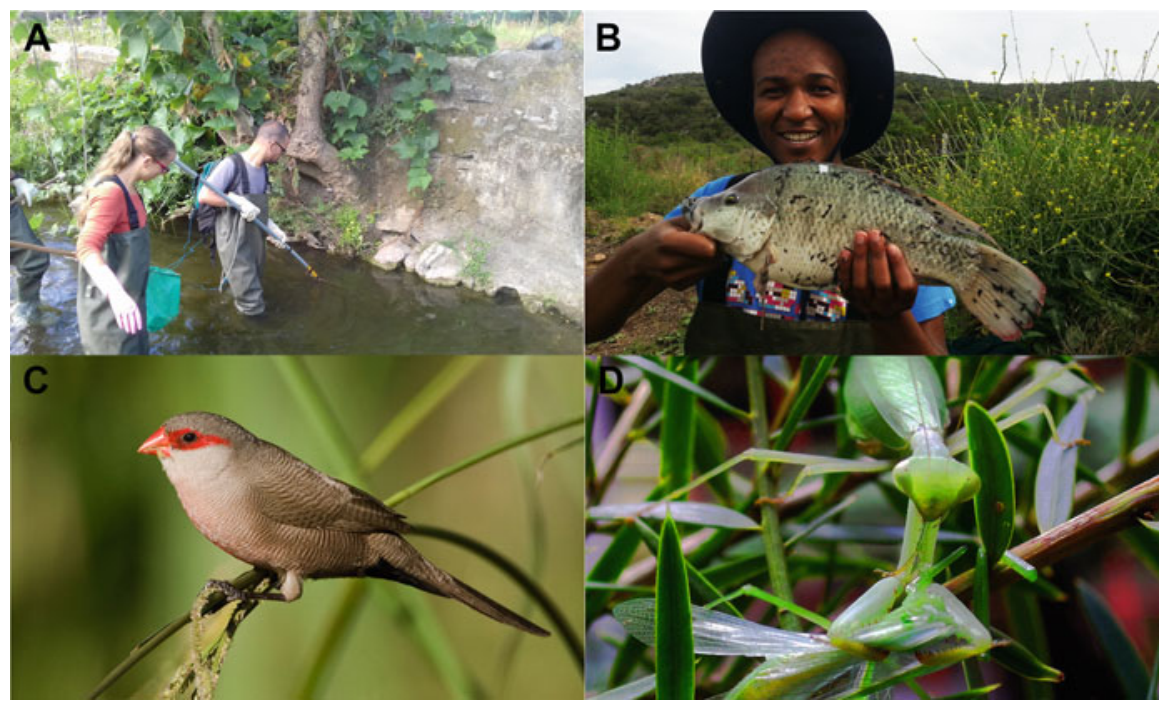

Fig. 27.1 Some of the highest impacting invasive species that South Africa has spread around the world. (a) The African clawed frog, Xenopus laevis being electro-fished in a river in Portugal, (b) the Mozambique Tilapia, Oreochromis mossambicus, within its native range, (c) the Common Waxbill, Estrilda astrild, and (d) the South African Mantis, Miomantis caffra 
for these species into other countries (Lombaert et al. 2010; Faulkner et al. 2017b). Therefore, in addition to native species, we also consider some of the alien species that have been moved through South Africa.

\subsection{Methods}

To identify species, we started with a list provided in Picker and Griffiths (2011), and augmented this with published databases of known alien species (Welcomme 1988; Long 2003; Lever 2005; Kraus 2009; Dyer et al. 2017; (Froese and Pauly 2019); WRiMS 2019), our expert knowledge and consultation with key researchers (see acknowledgements).

In many cases, the provenance of invasions are not known, and since most invasive species have widespread distributions (e.g. Blackburn and Duncan 2001; Tingley et al. 2010), we included every species that has an established population and that has part of its native range within South Africa. This inclusive approach has been followed elsewhere (see Pyšek et al. 2020, Chap. 26). However, species that have multi-continental distributions (including a portion of South Africa), and which may in addition have some introduced populations, were not included (but these birds are included in Supplementary Table S27.1). Where it was known that the population did not come from South Africa, we note this in the textual account for the species and in Supplementary Table S27.1.

We only considered species where populations were known to have become established (sensu Richardson et al. 2011) outside their native range. We did not include any re-introductions of species within or contiguous with their native range (e.g. zebras, rhinos, giraffe, elephants, etc. see Long 2003), or those that might be extralimital but within South Africa (see Maciejewski and Kerley 2014). We excluded species that had been introduced but are no longer known to be present (although some are mentioned when pertinent, below). We also excluded any species from South Africa that had deliberately been introduced elsewhere as biocontrol agents. In this way, we attempt to provide a species list of fauna from South Africa that are currently established elsewhere in the world.

\subsection{Results and Discussion}

Our study suggests that, unlike plants (Pyšek et al. 2020, Chap. 26), South Africa is clearly a net receiver of alien animals. A total of 629 alien animal species are recorded as established in South Africa (van Wilgen et al. 2020, Chap. 1, Table 1.1), but only 34 native South African species are established in other countries (see Table 27.1). Moreover, many of the animals (at least 20\%) detailed in this chapter likely did not have their origins from South Africa (Table 27.1). 
Table 27.1 South Africa is a net recipient of invasive animals across taxonomic groups

\begin{tabular}{lllcl}
\hline Group Taxon & $\begin{array}{l}\text { Number of invasive } \\
\text { species donated }\end{array}$ & $\begin{array}{l}\text { Number of invasive } \\
\text { species received }\end{array}$ & $\begin{array}{l}\text { Bridgehead } \\
\text { for invasions }\end{array}$ & References \\
\hline $\begin{array}{c}\text { Terrestrial } \\
\text { vertebrates }\end{array}$ & 26 & 30 & 1 & $\begin{array}{c}\text { Measey et al. } \\
\text { (2020, Chap. 5) } \\
\text { Janion-Scheepers } \\
\text { and Griffiths } \\
\text { Invertebrates }\end{array}$ \\
$\begin{array}{c}\text { Freshwater } \\
\text { animals }\end{array}$ & 1 & 466 & 4 & $\begin{array}{c}\text { (20), Chap. 7) } \\
\text { (2020, Chap. 6) }\end{array}$ \\
$\begin{array}{c}\text { Coastal species } \\
\text { Robinson et al. } \\
\text { (2020, Chap. 9) }\end{array}$ \\
\hline
\end{tabular}

Data on the numbers of animal species native to South Africa and invasive elsewhere in the world are from this chapter. Species were included only when evidence was well documented and the species is believed to still be established (i.e. the numbers below will likely be under-estimates). Note that even if species have South Africa as part of their native range, invasive populations elsewhere in the world need not have originated from South Africa (i.e. South Africa was not a "donor")

There are several possible reasons for the observed difference between plants and animals donated from South Africa. Firstly, databases on alien animals are confined largely to vertebrates, and established populations of invertebrates are likely to be far greater than we record here, but difficult to detect in the literature. One justification for this assertion is that the most numerous taxa represented in our list are the birds, which are probably the best taxon reported on in databases and the literature (e.g. Duncan et al. 2003). However, despite providing a large number of candidate species, very few are known to have been introduced from South Africa (4 out of 14 in Supplementary Table S27.1). This may mean that our chapter gives an unrealistically low representation of South African non-avian animals alien in other countries. Secondly, the scientific literature tends to be biased toward European and North American hubs, and poorly reflects alien species in Africa (e.g. van Wilgen et al. 2018). Thirdly, it could be that South African animals have few areas in the world for which they are suitable, or that they are particularly not invasive. This seems unlikely as South Africa has many areas of the world that are climate matched (Richardson and Thuiller 2007; van Wilgen et al. 2020, Chap. 1), and there are a considerable number of domestic exotic animals (see below). Lastly, South Africa underwent a hiatus in global trade from the United Nations resolution (no. 1761) in 1962 due to restrictions imposed by many countries reacting to the then apartheid regime. Sanctions only began to be lifted in the early 1990s (Evenett 2002). This period relates to the start of an exponential increase in global trade (Federico and Tena-Junguito 2017), and commensurate invasions (Seebens et al. 2017). It is possible that as trade from South Africa during this time was reduced, the contribution of animal species did not reach its potential levels. It would be important therefore to ensure through legislation that the introduction debt (sensu Rouget et al. 2016) built up during this time does not result in a future glut of animal invasions from South Africa. 


\subsubsection{Pathways}

Only three species (Estrilda astrild, Oreochromis mossambicus and Xenopus laevis) are related to deliberate commercial trade that has resulted in many invasive populations globally. Their footprints are large, and have been the focus of considerable research. The other species are all introduced to one or two areas in single events, and have attracted considerably less research attention.

Stowaways are particularly unusual in our list, but include geckos, spiders, butterflies and mussels. Only two examples of contamination occur in our list, both of marine organisms. Other species were deliberately transported, with the animals subsequently escaping or being intentionally released in new areas.

Whether it was Frank Hibben, the man responsible for introducing Gemsbok to New Mexico, or Pablo Escobar, whose Hippos now inhabit Columbian rivers, many of the pathways recorded here reflect maverick individuals who wanted these African animals in their own countries. Some, such as the Mauritian port director, Gabriel Regnard, introduced many alien species in an attempt to 'improve' the diversity of the local fauna. Others were motivated by conservation and poverty alleviation, such as the movement of freshwater fish in the 1930s from hatcheries in Jonkershoek and Pirie to English speaking countries in southern and eastern Africa. Douglas Hey, then Director of Nature Conservation of the Cape Province, presided over the importation and breeding of large numbers of fish species sent to him from Europe and North America ( $c f$ van Wilgen 2020, Chap. 2). His belief that he was aiding communities throughout the region did not require any evidence in the form of economic justification. Instead, his position as Director allowed him to continue experimenting with new species for decades. Hey was also responsible for supplying tertiary and research institutes with African Clawed Frogs (van Sittert and Measey 2016). The actions of individuals continue to impact invasions in the region, as seen by the relatively recent activities of Adrien Piers introducing Red Claw Crayfish into Swaziland (and their subsequent invasion into South Africa and Mozambique: Nunes et al. 2017b; Weyl et al. 2020, Chap. 6), Zambia and from there to Zimbabwe (see Welz 2017). While legislation may prevent many potential introductions, the role of mavericks driven by their own convictions will remain a problematic issue for the introduction of animals from South Africa and elsewhere. This is especially true now that e-commerce has opened up the possibility for many more species to reach individuals with more conviction than time to consider potential outcomes of their actions ( $c f$ Faulkner et al. 2020, Chap. 12).

\subsubsection{Non-South African Origins}

For many of the species listed below, we are not sure that the population that became invasive originated in South Africa. In some cases (e.g. Hippopotamus, Gemsbok and African Sacred Ibis), we know that it did not: $20 \%$ of cases on our list (Supplementary Table S27.1). But we have still included an account here because 
these species are known to have distributions that include South Africa ( $c f$ Pyšek et al. 2020, Chap. 26). Compared with many other countries on the continent, South Africa has considerable trade relations with the rest of the continent, and the world through several international airports and three large shipping ports (Faulkner et al. 2017a). This affords it ample opportunity to have become an important donor. However, the major pathways implicated in the spread of South African vascular plants around the world (horticultural trade, agricultural trade; Pyšek et al. 2020, Chap. 26), are absent for South African animals. Much of the trade in large mammals appears to have gone through the auspices of zoos and private collections (e.g. Hippopotamus, Gemsbok).

\subsubsection{South Africa as a Bridgehead for Invasions}

South Africa is recognised as having had a long history as a major commercial hub for southern Africa, and in some cases for the continent (Faulkner et al. 2017a). There are documented historical examples of how South Africa has acted as a bridgehead for invasions elsewhere on the continent (Lombaert et al. 2010). Below, we provide some examples of this movement. Although not exhaustive, they serve to show the importance of this effect, which is arguably greater than that South Africa has had for direct donations of alien animals.

\subsubsection{Forestry Pests}

The spread of insect pests of trees is an increasing problem in Africa (Graziosi et al. 2019). Bridgehead effects are the case for insect pests of forest plantations in South Africa, especially those infesting species of Eucalyptus (Faulkner et al. 2017b). South Africa is one of only a small number of countries where insect pests of Eucalyptus have been reported for the first time outside their native range and subsequently spread to other countries (Hurley et al. 2016). One example is the Eucalypt Snout Beetle, Gonipterus sp. 2 (formerly Gonipterus scutellatus), which was first reported in South Africa in 1916 (Tooke 1955), and over the next decades reported in other African countries as well as southern Europe (Mapondera et al. 2012). In fact, the majority of alien insect pests of eucalypts in sub-Saharan Africa were first reported in South Africa (Hurley et al. 2017). These include the Bronze Bug, Thaumastocoris peregrinus, the Eucalypt Longhorn Beetles, Phoracantha spp., and the Bluegum Psyllid, Ctenarytaina eucalypti. However, assumptions on the inter- or intra-continental spread of alien species based on first report data is not always accurate, as sampling effort can differ considerably between countries (Hurley et al. 2017).

The introduction pathways of forest insect pests from South Africa into other countries is generally not known. However, likely pathways for the introduction of wood boring insects such as Eucalypt Longhorn Beetles, included as stowaways on 
wood packaging material, and the timber trade (Meurisse et al. 2018). Likely pathways for leaf feeding insects such as the Bronze Bug and the Bluegum Psyllid, include contaminants on plants, and as stowaways on various commodities (Meurisse et al. 2018). These insects can also be transported as stowaways on people and their luggage, for example the Bronze Bug has been reported to attach itself to peoples' clothing and hair. For neighbouring countries, introduction may occur simply by natural dispersal, assisted by the wide distribution of the host trees (eucalypts) in these countries.

A number of insects native to South Africa have expanded their host range to include non-native plantation trees, namely eucalypts and pines. Examples include the Chrysomelid beetles, Colasposoma spp., the Lymantrid Moth, Euproctis terminalis, and the Saturniid Moth, Imbrasia cytherea (Roux et al. 2012). The probability of these insects spreading to other countries seems likely to increase due to their increased population and the availability of these hosts.

\subsubsection{Crayfish}

Four species of freshwater crayfish have been introduced into South Africa for aquaculture: the Smooth Marron, Cherax cainii in 1976, the Common Yabby, C. destructor and the Redclaw Crayfish, C. quadricarinatus, in 1988, and in the ornamental trade Procambarus clarkii, the Red Swamp Crayfish in 1982 (Nunes et al. 2017a). Some of these crayfish species were then further moved introduced from South Africa into neighbouring countries. For example, C. destructor and C. quadricarinatus were imported from South Africa in 1992 to Livingstone in Zambia (van den Audenaerde 1994; Mikkola 1996). The introduction of Cherax destructor failed but $C$. quadricarinatus managed to establish in the wild (Mikkola 1996). Cherax quadricarinatus was deliberately moved from Livingstone to several areas in Zambia, but was only recently confirmed as established in the Kafue River system (Douthwaite et al. 2018). Other bridgehead invasions by C. quadricarinatus into several river systems in middle Zambezi and Limpopo River catchments have occurred as a result of both intentional and accidental introductions from Swaziland. For example, C. quadricarinatus was also introduced into the Kafue River in 2001 from Swaziland, and it has since appeared in the upper and middle Zambezi sub-catchments after escaping from nearby fish farms (Douthwaite et al. 2018). Elsewhere, C. quadricarinatus escaped from aquaculture facilities in Swaziland and as a result of downstream spread and subsequent dispersal, it is now established in several river systems in Swaziland, South Africa and Mozambique (Nunes et al. 2017b). The C. quadricarinatus invasions in southern Africa, including ongoing invasion in South Africa, are some of the worst on the continent. Its presence in upper catchments of major rivers such as the Zambezi River is likely to ensure a sustained influx of propagules into downstream river systems and adjacent river systems such as Okavango Delta are now exposed to a major invasion risk (Nunes et al. 2016). 


\subsubsection{Frogs}

Xenopus laevis was moved extensively around the world (Box 27.1), but the global trade was an order of magnitude smaller than the regional trade in frogs for academic research in southern and eastern Africa (van Sittert and Measey 2016). While the majority of these animals were intended for dissections, it seems likely that many would have been released. Most of these institutions would have been within the native range of this species (see Furman et al. 2015), and thus any introductions would likely manifest as genetic introgression with native populations. Measey et al. (2017) report the finding of one such example, with the genetic signature of X. laevis from Jonkershoek (near Stellenbosch, Western Cape) mixed with animals from a local clade on the university campus in Port Elizabeth.

\section{Box 27.1 A Model Species Turned Invader-Xenopus laevis}

The African Clawed Frog, Xenopus laevis, has a particularly interesting history that have carried this rather atypical anuran into laboratories of tertiary institutions the world over, eventually rising to the status as the 'model amphibian' (Tomlinson et al. 2005), and directly resulting in the deliberate or accidental release of animals on four continents (Measey et al. 2012). In 2018, there were nearly 1000 publications focused on this species from diverse subject areas including Biochemistry, Genetics and Molecular Biology; Agricultural and Biological Sciences; Medicine; Neuroscience and Pharmacology, Toxicology and Pharmaceutics. The African Clawed Frog has achieved this remarkable success as individuals are easily maintained in laboratories, and importantly will reproduce throughout the year when stimulated with hormones. This allows easy access to embryos and tadpoles that are pivotal to the understanding of many research fields. This frog was the first vertebrate to be cloned, leading to the Nobel Prize of Sir John Gurdon in 2012. Gurdon et al. (1958) showed that nuclear information present in cells from the intestines of tadpoles are pluripotent, growing into new individuals when implanted into an enucleated egg.

Described by the French naturalist Daudin in 1802 from a specimen of unknown provenance and no longer in existence, the African Clawed Frog became a well known animal of curiosity over the next few decades. Live specimens arrived from South Africa in European capitals and were prominently displayed in large water filled jars. By the end of the century, animals were breeding in captivity, and the development of their midwater suspension feeding larvae was being studied (Gurdon and Hopwood 2003).

In South Africa, tertiary institutions were being formed at the beginning of the twentieth century, and X. laevis was the amphibian of choice for dissection, due to their high density in local dams and ease of maintenance prior to use. Bringing large numbers of this frog into the laboratory led to its local use in physiology research. So it was that when British biologist, Lancelot Hogben 
Box 27.1 (continued)

arrived in Cape Town in 1927, X. laevis was already in the Physiology Department (Gurdon and Hopwood 2003). Hogben recognised the potential of using X. laevis for studies of endocrinology. In 1930 he published a paper in which he explained how ovulation could be induced in $X$. laevis females through injection of ox pituitary (Hogben 1930). This soon led to the realisation that urine from a pregnant woman could induce the same effect due to the presence of gonadotrophins, and very quickly the Hogben test became a standard for pregnancy testing in the United Kingdom and then throughout the British empire.

The use of $X$. laevis for pregnancy testing necessitated the export of thousands of live animals from the Cape. In the 1940s, the Cape Provincial Administration's Department of Nature Conservation, under Douglas Hey (see van Wilgen 2020, Chap. 2), saw the need for these frogs to be supplied, and included them among their cultures of alien fish that they were breeding and disseminating. That decade they shipped 32,000 X. laevis overseas, but a larger quantity were being distributed around British colonies in southern and East Africa for dissections in universities (van Sittert and Measey 2016). The 1950s saw the peak in demand and supply of X. laevis from Jonkershoek (near Stellenbosch in Western Cape Province) supplying overseas and domestic orders, and Pirie Fish Hatchery (near King Williams Town in Eastern Cape Province) supplying tertiary institutes in southern Africa (van Sittert and Measey 2016), totalling some 150,000 animals (figure below).

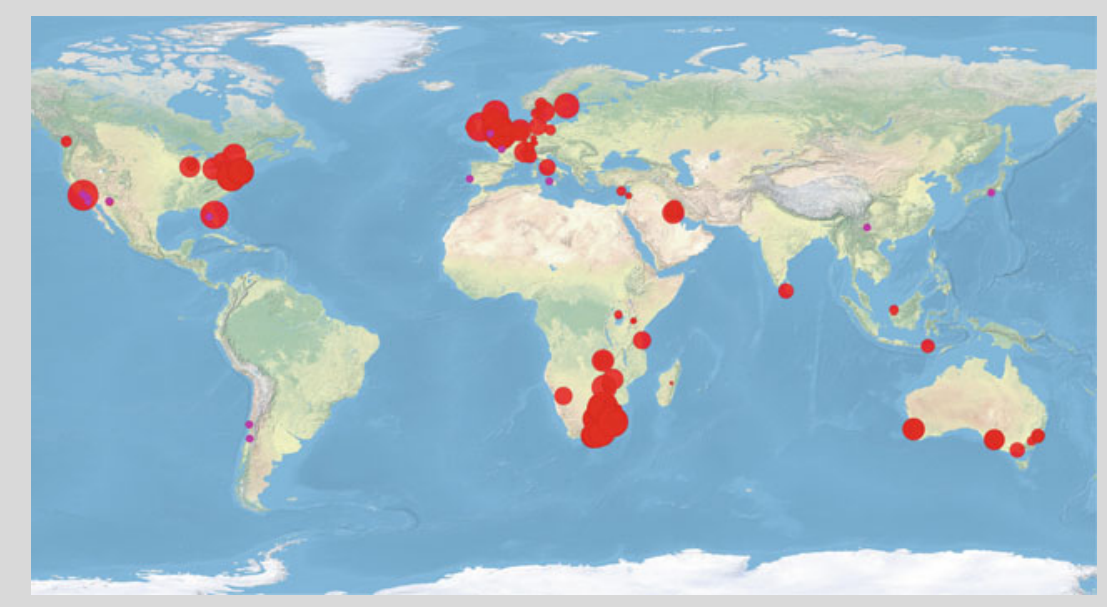

The destinations of African Clawed Frogs, Xenopus laevis, shipped around the world from South Africa between 1940 and 1970 (data from van Sittert and Measey 2016) shown proportionately in red circles. Purple dots show the locations of currently known invasive populations of $X$. laevis

(continued) 
Box 27.1 (continued)

The movement of large quantities of animals from South Africa quickly saw populations establish in other parts of the world. The first was found on Ascension Island in the 1940s, although the provenance of this population is unknown and it is now thought to be extinct (Loveridge 1959; Measey et al. 2012). By the 1960s, populations had established in several locations in the southern US states, Chile and in the UK. In the 1980s more populations began being recorded in Europe (Measey et al. 2012), and there are still more being discovered (e.g. Peralta-García et al. 2014; Hill et al. 2017). Although the historical pathway detailed above is recognised as donating much of the genetic stock (Lillo et al. 2013; Lobos et al. 2014; but see de Busschere et al. 2016), it has been suggested that laboratory populations have been responsible for secondary movements of many captive (and subsequently released) laboratory stocks (van Sittert and Measey 2016; Sousa et al. 2018). More recently, the pet trade has been implicated in the movement in excess of 100,000 albino animals annually into the US (Measey 2017). The first established albino population of $X$. laevis has now been discovered on the Chinese mainland (Wang et al. 2019). This marks a shift from invasive populations principally associated with the scientific trade to those moved for the pet trade.

\subsubsection{Fish}

Several species of trout (e.g., Brown Trout, Salmo trutta, and Rainbow Trout, Oncorhynchus mykiss), Black basses (e.g., Largemouth Bass, Micropterus salmoides), and Cyprinids (e.g., Common Carp, Cyprinus carpio) were introduced into South Africa and from there to several countries in southern Africa (de Moor and Bruton 1988; see Welcomme 1988 for a complete list of 24 species). For example, S. trutta was introduced into South Africa in 1892 from England from where it was then introduced to Swaziland (1915), Lesotho (1907-1914), Zimbabwe (1907), Tanzania (1934) and even the sub-Antarctic Marion Island (1964) (Weyl et al. 2017; Box 12.1 in Faulkner et al. 2020). Similarly, C. carpio was distributed to Botswana, Lesotho (1965), Namibia, Zambia (1980), and Zimbabwe (1925) (Ellender and Weyl 2014), and Micropterus salmoides into Namibia and Zimbabwe (1932), Botswana and Lesotho (1937) and Swaziland (1947) (Bell-Cross and Minshull 1988). 


\subsubsection{Domestic Exotics}

It seems likely that South Africa will continue to be a donor of alien animal species to the rest of the world, but the trends reported here suggest that these species will be mostly transported accidentally, rather than the large scale deliberate introductions of (mostly vertebrates) seen in the past. One indication of which South African species may pose a future threat of invasion elsewhere in the world are those that are currently domestic exotics ( $c f$ Guo and Ricklefs 2010). Examples include the Painted Reed Frog, Hyperolius marmoratus, the Guttural Toad, Sclerophrys gutturalis and the Common Dwarf Gecko, Lygodactylus capensis (see Measey et al. 2020, Chap. 5). We show that many South African species alien elsewhere are currently domestic exotics in South Africa, with invasive or extralimital populations moving between biomes (see Measey et al. 2020, Chap. 5). Domestic exotic species appear to be a logical starting point for raising concerns and preventing movements of South African animals elsewhere in the world, and can provide useful information for risk and impact assessments.

\subsubsection{Taxonomic Considerations}

Of the taxa that we included below, some groups were conspicuous by their absence, and we discuss here some of these taxonomic considerations.

There are many South African animals, and in particular the mammals, which have been introduced into public and private zoological collections around the world. Many are kept outdoors but despite incidental escapes, suggesting some level of appropriate climatic tolerance, few have been able to become established outside of their native range. It is of particular note that South Africa has a high diversity of ungulates (Spear and Chown 2009), and that the Gemsbok and three suriformes (Hippopotamus, Bushpig and Warthog) have been reported as established elsewhere in the world. Many other populations of South African ungulates exist in zoos and private collections, which have international stud books and means of breeding between them such that they do not need to be re-supplemented from native stocks. These captive populations are for the most part carefully managed. South Africa is also a centre of diversity for the Afrotheria, an African clade of mammals with diverse morphological characteristics. None are known to have established populations outside of their native ranges.

The taxonomy of Green Monkeys, listed by Long (2003) as Cercopithecus aethiops, and established in the Caribbean and Cape Verde, has now been updated such that the introduced West African Green Monkey, Chlorocebus sabaeus, is the introduced species while the South African Vervet Monkey, Chlorocebus pygerythrus, has not been introduced.

Birds have been studied intensively and their current distributions as well as introductions are well recorded so that the databases are particularly advanced 
(Duncan et al. 2003; Carrete and Tella 2008; Dyer et al. 2017). It is maybe for this reason that our list has more birds than any other taxa (41\%). Several wide-ranging bird species (over two or more continents) that have part of their distribution in South Africa, also have invasive populations (Dyer et al. 2017). These have not been included in the list of species in this chapter (but see Supplementary Table S27.1). Of the other birds, many of the introductions are from species with distributions across most of sub-Saharan Africa, and South Africa is not thought to be the source of the established population. Only a small number of South African birds have been traded and have formed established populations around the world. Of these, only the Village Weaver, Ploceus cucullatus, Cape and Yellow Canaries, Serinus canicollis, S. flaviventris, and the Common Ostrich, Struthio camelus, are known to have been introduced from South Africa (although the Ostrich may have been supplemented with stock from Sudan). Others are now extinct, like the Blue-breasted Cordon-bleu Uraeginthus angolensis on St. Helena (Lever 2005).

Some birds, such as the Pied Crow, Corvus albus, undergo short movements out of their range and pairs have occasionally been observed staying for long periods North of the Sahara, and as far as Spain and Portugal (Pepe 2017). Some breeding populations of this species have already been extirpated (Dyer et al. 2017). There is one example of a breeding pair in Morocco, and another of an individual on a rubbish dump in Jodhpur, India (Saikia and Gaswami 2017). It has been suggested that the pathway for some of these far reaching individuals may be ship assisted, as is the case for the House Crow, Corvus splendens (see Measey et al. 2020, Chap. 5), and if this is the case then it seems likely that Pied Crows pose a considerable future threat for becoming invasive in many parts of the world. A number of South African reptiles are in the pet trade and are known to survive after release. For example, Krysko et al. (2011) documented a number of species found released (but not established) in Florida, including the Leopard tortoise, Stigmochelys pardalis (see Measey et al. 2020, Chap. 5), Turner's Thick-toed Gecko, Chondrodactylus turneri and Bibron's Thick-toed Gecko, C. bibronii (there are suggestions that an established population of $C$. bibronii does occur in Florida, but this could not be verified).

South Africa has three species of amphibians that have established populations outside of the country. It is noteworthy that one (the Guttural Toad) is also invasive in South Africa as a domestic exotic (Measey et al. 2020, Chap. 5), and two (the Guttural Toad and the African Clawed Frog) are the subject of control measures in the country (Davies et al. 2020, Chap. 22). In addition, there are some incidental records of South African amphibians, such as Fornasini's Spiny Reed Frog, Afrixalus fornasini in Florida (Krysko et al. 2011).

While South Africa has a high diversity of marine and freshwater fishes (Skelton 2001), very few have been introduced elsewhere in the world. Of those that have, detailed below, it has not been confirmed that South Africa was the source of the alien populations. However, South Africa has played an important role as a bridgehead for invasions elsewhere on the continent (see Sect. 27.3; Weyl et al. 2020, Chap. 6). 
The East African Lowland Honey Bee, Apis mellifera scutellata, is native to a large part of East and southern Africa, including much of South Africa. This sub-species is often preferred over the European sub-species, A. m. lingustica, as it produces a larger quantity of honey. However, A. $m$. scutellata have a reputation for being more aggressive. Many apirists have hybridised the two sub-species to produce so-called 'Africanized honey bees', and these bees are extensively used and invasive in Brazil and North America. As this is a hybrid of a sub-species, we have not included this taxon in our list of alien animals from South Africa.

It should also be noted that there may well be parasites that have travelled with the hosts mentioned in this chapter and have successfully formed their own invasive populations (le Roux et al. 2020, Chap. 14). Although these are not often reported, and invasive populations benefit from enemy release (e.g. Torchin and Mitchell 2004), there are some studies from South African examples. The African Clawed Frog, Xenopus laevis, has one of the most diverse parasite faunas, with 20 metazoan parasites within its native range (see references in Schoeman et al. 2019). Some have been found in invasive populations, including the monogenean Protopolystoma xenopodis in populations from California, France and Portugal, and the cestode Cephalochlamys namaquensis in California and France (Schoeman et al. 2019), however none are known to have moved hosts to local species. Host transfer has been recorded between four out of six monogeneans from introduced O. mossambicus to local Chiclid fish, Cichlasoma callolepis and C. fenestratum, in Lake Catemaco, Veracruz, Mexico (Jiménez-García et al. 2001). We have not included separate accounts for parasites, or included them in our totals.

\subsection{Species Accounts}

\subsubsection{Mammals}

\subsubsection{The Hippopotamus, Hippopotamus amphibius}

Pablo Escobar, the notorious drug baron, maintained a private zoo in his jungle hideout, Hacienda Nápoles, in Magdalena, between Medellin and Bogota in Columbia. In the 1980s, he introduced three pairs of Hippopotamus from zoos in the US, which began breeding in Hacienda Nápoles and subsequently escaped into the Magdalena River growing to an estimated population of 20 to 40 individuals (Buriticá 2014; Valderrama Vásquez 2012). Hippopotamuses are native to all of sub-Saharan Africa, but are now considered Vulnerable by the IUCN due to habitat change and hunting. Impact of the increasing population in Columbia included attacks on fishermen, killing of livestock, destruction of crops and general fear among the local population, including stopping fishermen from accessing their fishing grounds (Valderrama Vásquez 2012). The control operation is controversial as the hippos are still an attraction at the theme park that was made from Escobar's home. This has meant that although they pose a very real threat to people living 
along the river, culling is rare, and instead one male was castrated and flown back to Hacienda Nápoles by helicopter (Valderrama Vásquez 2012; Restrepo Betancur et al. 2016). Currently, the population at Hacienda Nápoles still exists and females breed with young males that left the group and invaded stretches of the Magdalena River.

\subsubsection{Common Warthog, Phacochoerus africanus}

Common Warthogs are native to a large part of sub-Saharan Africa, excluding the Congo basin and the arid western areas of southern Africa. They were first reported from within the Chaparral Wildlife Management Area, South Texas, USA, in 2014 (Tompkins 2015). They are known to have been kept on private ranches in the area, and are thought to have burrowed under these fences to enter into the protected area. Today, Common Warthog are regularly seen on camera traps in the Chaparral Wildlife Management Area together with their offspring (W. Gann pers. comm. May 2019). Currently, there have been no studies made on this population, but their impacts are thought to be similar to the rapidly expanding population of Feral Pigs (Sus scrofa; see Measey et al. 2020, Chap. 5) also in the same area.

\subsubsection{Bushpigs, Potamochoerus porcus}

Bushpigs are native to a large swathe of eastern Africa, from Ethiopia in the north, to Mossel Bay on South Africa's south coast. They are thought to have been introduced to Mayotte in the Comoros Islands and to Madagascar, but whether they were introduced or dispersed naturally (via rafting on papyrus) is still contested (Long 2003; Oliver 1993). On the one hand, the Malagasy and Comoro forms are so distinct from those on the mainland that they have been named as different subspecies. However, this is not unexpected given the morphological changes that we know invasive populations undergo relatively quickly (see Box 27.2). Others argue that bushpigs were introduced (Vercammen et al. 1993), probably with the movement of peoples to these islands. Such an introduction would have to date to pre-Austronesian times, some 2000 years BP (Blench 2008). Bushpigs are now widespread throughout Madagascar, missing only from the deforested central plateau and major townships (Vercammen et al. 1993). These animals play an important part in the local bushmeat trade (Golden 2009; Randrianandrianina et al. 2010), may contribute significantly to the dispersal of fruits (although probably destroying many, Ganzhorn et al. 1999), and form an important prey item of the threatened Fosa, Cryptoprocta ferox. They are also an important reservoir for African Swine Fever (Roger et al. 2001). 


\section{Box 27.2 Spatial Sorting of African Clawed Frogs in France}

Invasive populations undergoing expansion can evolve life-history traits increasing their capacity to reproduce, disperse, and survive (Wilson et al. 2009; Burton et al. 2010; Stevens et al. 2010). Dispersing individuals at the range edge of an expanding population have been found to differentially allocate resources compared to those at the core (Burton et al. 2010; Bonte et al. 2012; Chuang and Peterson 2016; Travis et al. 2010). The resource allocation influence of life-history traits that are dispersal relevant may result in spatial differentiation of expanding populations, also known as spatial sorting (Shine et al. 2011). Evidence of spatial sorting can be found in a plethora of taxa, including Orthoptera (Simmons and Thomas 2004), Lepidoptera (Hughes et al. 2007; Karlsson and Johansson 2008), Hymenoptera (Léotard et al. 2009), Amphibia (Llewelyn et al. 2010; Brown et al. 2013; Hudson et al. 2015), Aves (see Measey et al. 2020, Chap. 5) and Pinales (Cwynar and MacDonald 1987). If dispersal-relevant traits are inherited, gene expression will accumulate at the range edge. These traits can be morphological, (e.g. larger wing size, Simmons and Thomas 2004; longer legs, Llewelyn et al. 2010), behavioural (e.g. altering movement patterns, Alford et al. 2009), and physiological (e.g. greater endurance, Llewelyn et al. 2010). This results in individuals at the range edge evolving a novel phenotype that is adept for dispersal and differs from that at the core; evolution in space rather than through time (Shine et al. 2011).

In western France, the African Clawed Frog, Xenopus laevis, (figure below) was released into the natural environment when a breeding facility for the CNRS closed in the 1980s (Fouquet and Measey 2006). Individuals have been expanding from this single introduction point colonizing water bodies now covering an area $\sim 2000 \mathrm{~km}^{2}$ (Louppe et al. 2017). An estimated overland spread in the invasive range $\sim 1 \mathrm{~km}$ per year, although dispersal through waterways appears to be much faster (Fouquet and Measey 2006).

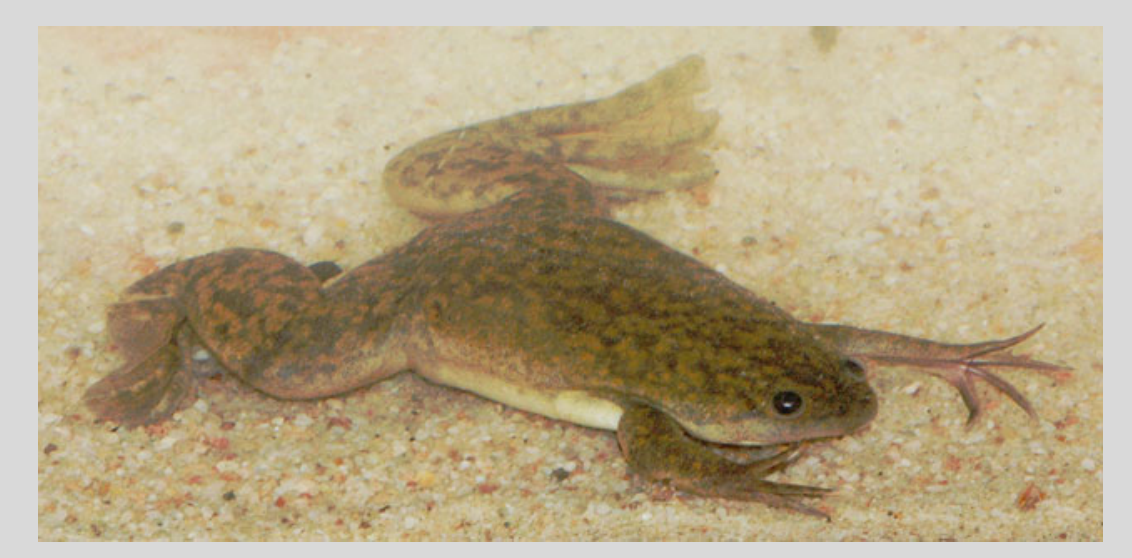

An adult African Clawed Frog, Xenopus laevis 


\section{Box 27.2 (continued)}

At the edge of the distribution individuals have been found to allocate less resources to reproduction than individuals at the core. Individuals at the edge exhibit a decrease in the relative mass of reproductive organs during the peak of the breeding season (Courant et al. 2017a). Evidence suggests that increased energy resources are allocated to dispersal for edge $X$. laevis individuals (Louppe et al. 2017). Males at the core show better endurance capacity than females due to their relatively longer limbs and lower body mass. At the edge, both males and females have smaller body sizes than those at the core. Frogs from the edge may also have improved swimming performance due to the relative increase in limb length. This would assist in dispersal, increasing dispersal by overland migration and through rivers and streams (Louppe et al. 2017).

The trade-offs displayed by X. laevis between reproduction, mobility, and morphology can be constrained by the metabolism of the individual. At the range edge, where individuals display a decrease in reproductive ability and an increase in dispersal (through an increase in mobility), individuals exhibit a lower standard metabolic rate (SMR) (Louppe et al. 2018). At the core of the distribution males display a higher SMR than females, whereas at the edge females displayed a higher SMR than males explaining the differences in endurance capacity between males and females (cf Hulbert and Else 1981). A lower SMR for males at the edge can enhance their ability to allocate resources to dispersal, whereas a higher SMR for males in the core can enhance resources for reproduction. The SMR in females at the edge is lower than females at the core but higher than males at the edge. This indicates that fewer resources are allocated to reproduction at the edge overall for males and females (Louppe et al. 2018).

The allocation of resources to dispersal ability (morphology, endurance, distance travelled) rather than reproduction is expected to influence the growth rate and lifespan of X. laevis (e.g. Phillips et al. 2010; Amundsen et al. 2012). However, no differences of growth rate and life span have been found for individuals at the core and the edge (Courant et al. 2019a). This indicates that an accelerated growth rate in individuals is not a dispersal-relevant trait for this expanding population. A higher survival probability has been found for individuals at the edge compared to the core (Courant et al. 2019b). Thus, survival rather than faster development and longer lifespan is displayed by individuals of $X$. laevis at the edge. The spatial sorting of $X$. laevis in western France is evidence of rapid evolution just $\sim 40$ years after their introduction (Courant et al. 2019b). 


\subsubsection{Gemsbok, Oryx gazella}

The Gemsbok, Oryx gazella, is native to Namibia, Botswana and northwestern arid areas of South Africa. Between 1969 to 1977, 93 Gemsbok were introduced to White Sands Missile Range, part of the Chihuahua Desert of New Mexico, USA, from captive-bred stock of unknown provenance. The aim was to increase sport hunting for wealthy visitors (Bender et al. 2003). By the early 2000s, the population had grown to between 3000 and 6000 individuals, and had spread over an area of $15,000 \mathrm{~km}^{2}$ in southern New Mexico, to become the most numerous ungulate in the state (Bender et al. 2003). Gemsbok tested were found to have significant infectious diseases, which may affect recovery of native ungulates, including Desert Bighorn Sheep, Ovis canadensis mexicana. They have been found to have considerable dietary overlap with another native ungulate, the American Pronghorn, Antilocapra americana (Cain et al. 2017).

\subsubsection{Birds}

\subsubsection{Common Ostrich, Struthio camelus}

The Common Ostrich, Struthio camelus, has been farmed in South Africa's Karoo since the 1860s, and the similarity between this region and South Australia was generally appreciated and Ostrich farming encouraged and facilitated by the local government (Iwanicki 1985). Birds were mostly imported from South Africa, but there is one notable importation of 12 birds from Sudan that were bred with the South African flock at Yanco Experimental Farm (Hastings and Farrell 1991). The Ostrich industry suffered a collapse in 1914, and the biggest farm near Port Augusta, South Australia, closed in 1916, selling most of its stock. However, some feral birds remained, and these were cared for by the new owners who farmed sheep. The flock north of Port Augusta now occur across at least three very large $(30,000+$ ha) properties, where they have been present for over 100 years. The total population still probably numbers fewer than 250 birds (perhaps even as low as 100) but they have been in rangeland country since the late 1800s and are most certainly self sustaining (R. Clarke pers. comm.). Despite ostriches being farmed in many other parts of the world, no other established populations are known (Lever 2005). Evans et al. (2016) listed their EICAT impact as Data Deficient.

\subsubsection{Egyptian Goose, Alopochen aegyptiaca}

The Egyptian Goose (a shelgoose and member of the subfamily Tadorninae) is native to nearly all of sub-Saharan Africa, including all of South Africa. It is invasive in the UK, northeast France, Belgium, the Netherlands, Germany, Denmark and Sweden. Populations are also recorded from the USA, Israel and United Arab Emirates. Egyptian Geese are known to have been introduced to East Anglia in the seventeenth 
century as an ornamental waterbird (Lever 2005; Sutherland and Allport 1991; see Kampe-Persson 2010 for a recent review). This became an established population (Sutherland and Allport 1991). From the 1950s onwards, Egyptian Geese were kept in many sites in Europe, but it seems that a population from The Hague began to expand rapidly and colonised all areas of The Netherlands by the end of the twentieth century, showing a classic invasion exponential expansion from the mid-1990s (Gyimesi and Lensink 2012). The Dutch population has spread into neighbouring countries and is currently expanding. Other noteworthy established populations have been documented in the USA states of Texas (Callaghan and Brooks 2016) and Arkansas (Smith and Fames 2012). This species is considered a pest requiring control in many urban areas of South Africa (cf Potgieter et al. 2020, Chap. 11), and may be implicated in movement of propagules of alien species, especially freshwater plants (Reynolds et al. 2015; cf. Hill et al. 2020, Chap. 4). Evans et al. (2016) listed their EICAT impact as Minor due to competition and nutrient loading.

\subsubsection{Pin-tailed Whydah, Vidua macroura}

The Pin-tailed Whydah, Vidua macroura, is native to much of sub-Saharan Africa but has been introduced to Puerto Rico in the 1960s via the pet trade (Lever 2005). Populations have been seen since the 1990s in California (Garrett and Garrett 2016), and in Florida since the mid-2010s (Greenlaw et al. 2014). This species is an obligate avian brood parasite, and most commonly parasitises the Common Waxbill in its native range (see below). The Pin-tailed Whydah became established in Puerto Rico following accidental releases from the pet trade, and switching to parasitise Orangecheeked Waxbills, also established on the island (Raffaele 1989). Other established populations are in southern California (and most likely in neighbouring Mexico) and Florida in the USA.

There is concern that this species may occupy a larger area of North America, especially given the existing populations of the Common Waxbill, and the Pin-tailed Whydah's ability to switch hosts (Crystal-Ornelas et al. 2017). Evans et al. (2016) listed their EICAT impact as Data Deficient.

\subsubsection{Laughing Dove, Spilopelia senegalensis}

The Laughing Dove, Spilopelia senegalensis, was introduced to Perth Zoological Gardens in 1898, and subsequently was released and has become widespread in Western Australia following a rapid population expansion in the 1930s (Forshaw 2015). It is not clear from where they originated, but they resemble the sub-Saharan form. This species appears to be a strong human commensal, and it has not spread far from Perth (Forshaw 2015). Laughing Doves are carriers of and form a reservoir for psittacine beak and feather disease, a common viral disease of captive birds in Australia (Raidal and Riddoch 1997). Other populations are recorded from Príncipe Island and Mafia Island (populations on the Mascarene Islands are believed to be 
from Asia) (Lever 2005). Evans et al. (2016) listed their EICAT impact as Minor due to disease.

\subsubsection{Village Weaver, Ploceus cucullatus}

The Village Weaver, Ploceus cucullatus, is native to a large part of sub-Saharan Africa, and in South Africa this species has undergone recent expansion due to its commensal habits (South African Bird Atlas Project). The South African form P. c. spilonotus was introduced to Réunion in 1880 and Mauritius in 1886 (Lahti 2003). It has been suggested that Village Weavers were deliberately released by their owner, Gabriel Regnard (Cheke and Hume 2010). On Mauritius, it is said to have displaced the introduced Cape Canary, Serinus canicollis, while both species continue to co-exist on Réunion (Jones 1996). The introduction of this species to Hispaniola is thought to be of the West African form, P. c. cucullatus (Wetmore and Swales 1931), and there have been other incidental records and sightings including the southern USA and southern Europe (see Lahti 2003). It is considered to be an agricultural pest, as it nests in large colonies which forage causing crop damage to grain crops. Accordingly, Evans et al. (2016) listed their EICAT impact as Minor.

\subsubsection{Lesser Masked Weaver, Ploceus intermedius}

Lesser Masked Weaver, Ploceus intermedius, is native to sub-Saharan Africa. It is listed as established in Taiwan, Yemen and United Arab Emirates (Lever 2005). Lesser Masked Weavers are known to breed in Chiba Prefecture, Japan since the 1960s (Eguchi and Amano 2004), with an estimated population around 10,000 breeding pairs (Brazil 2009). There is a somewhat smaller population on Taiwan, China (Brazil 2009). Their EICAT impact is listed as Data Deficient (Evans et al. 2016).

\subsubsection{Yellow Canary, Serinus flaviventris}

The Yellow Canary is native to South Africa, Botswana and Namibia. They were introduced to Ascension Island and St. Helena in 1776 (Brooke et al. 1995), where they are still established and said to have caused damage to soft fruit grown there (Lever 2005). Evans et al. (2016) listed their EICAT impact as Data Deficient.

\subsubsection{Cape Canary, Serinus canicollis}

The Cape Canary, Serinus canicollis, is native to southern Africa, and was introduced to a number of islands: St. Helena, Mauritius, Réunion and Tahiti (Brooke et al. 1995). Of these, introduction was only successful on Réunion between 1830 and 1860 (Jones 1996; Cheke and Hume 2010). The 1760 introduction to Mauritius later declined and eventually became extinct (Simberloff and Gibbons 2004). Barré 
(1983) states that $S$. canicollis was introduced from South Africa. Evans et al. (2016) listed their EICAT impact as Data Deficient.

\subsubsection{Common Waxbills, Estrilda astrild}

Waxbills have a long history in the bird trade, with records dating back to the nineteenth century in Brazil and Europe (Cardoso and Reino 2018), and 1820 to St. Helena (Brooke et al. 1995). A more recent introduction to Portugal in 1964 appears to be the source of an invasion on the Iberian Peninsula (Reino and Silva 1998). Common Waxbills in Europe are thought to have been wild-caught in northern Senegal (Sanz-Aguilar et al. 2014). They have a large distribution in sub-Saharan Africa encompassing arid and tropical zones, and including much of South Africa (Stiels et al. 2011). Given their introduction into Portugal and Brazil, it seems likely that some of the original populations were from Mozambique and/or Angola (Cardoso and Reino 2018). Today they are invasive in many regions in Brazil, the Iberian Peninsula (Spain and Portugal) as well as a host of islands within the tropics (Stiels et al. 2011). Due to their widespread introductions across the world, they have been dubbed as the most successful invasive tropical bird (Lever 2005). The Common Waxbill has the potential to be a much greater problem globally, especially in the tropics, but also in the subtropics and some temperate areas, including much of western Europe and southern and western USA and Mexico (Stiels et al. 2011). Their EICAT impact is listed as Data Deficient (Evans et al. 2016), but it has been argued that they have no impact in Europe (Cardoso and Reino 2018). There has been a great deal of research into this species as an invasion model in dispersal, behavioural (e.g. changes in personality) and evolutionary ecology (e.g. changes in ornamentation). Cardoso and Reino (2018) recently compiled an overview of the research on this species.

\subsubsection{Bronze Munia, Lonchura cucullata}

The Bronze Munia, Lonchura cucullata, is native to most of sub-Saharan Africa, and the eastern portion of South Africa. It was introduced to Puerto Rico in the mid-1500s with slave trafficking (from West Africa), such that it was abundant by the late 1870s (Frahnert et al. 2015), but their numbers in some areas are reported to be declining (de Jersey Gemmill 2015). One impact of the Bronze Munia is to act as a reservoir for brood parasitism by the Shiny Cowbird (Molothrus bonariensis). The fear is that this, and other introduced birds, could provide a foothold for the Shiny Cowbird to then parasitise native birds (Wiley 1985). Evans et al. (2016) listed their EICAT impact as Data Deficient.

\subsubsection{Yellow-Crowned Bishop, Euplectes afer}

The Yellow-crowned Bishop, Euplectes afer, is native to most of sub-Saharan Africa, but has formed established populations in Europe (Italy, Spain and Portugal: 
Carrete and Tella 2008), Florida (USA), Puerto Rico (since the early 1970s), Venezuela and Jamaica (since the late 1980s; Lever 2005). The European populations are thought to have resulted from the trade in wild-caught cage birds (Carrete and Tella 2008). Individuals in Europe are thought to have been wildcaught in northern Senegal in the mid-1980s (Sanz-Aguilar et al. 2014). Evans et al. (2016) listed their EICAT impact as Data Deficient.

\subsubsection{Helmeted Guineafowl, Numida meleagris}

Helmeted Guineafowl are known to have been introduced to Greece by the fifth century BC, and Italy by the first century AD, with possible introduction into Germany around this same time (Poole 2010). There are records in France dating back to the fifteenth century with animals reaching Britain in the sixteenth century. All of these introductions are associated with using animals as food, for their ornamental feathers and as display animals. During the early stages of introductions, birds remained scarce and highly sought after. Today, this species is raised commercially for the table in many parts of the world. Most of the European populations are extinct, although current records exist for the Canary Islands and Great Britain (DAISIE 2019). Other introduced populations include Japan, Yemen, West Indies, Brazil, Australia, New Zealand, and many islands: Annabon, Ascension, Canary, Cape Verde, Chagos, Comoros and the Mascarenes (Lever 2005; McKinney and Kark 2017). In addition to being invasive elsewhere in the world, they are an extralimital species in the Fynbos Biome of South Africa, where they were introduced in the late 1800s to improve sport-shooting (Brooke and Siegfried 1991; see Measey et al. 2020, Chap. 5).

Controversially, Helmeted Guineafowl have been used as a bio-control agent against ticks carrying Crimean-Congo hemorrhagic fever in Turkey (Şekercioğlu 2013). However, evidence suggests that they are themselves potential hosts for the same ticks they were released to control. Moreover, Helmeted Guineafowl are a known host of Newcastle disease (an important poultry virus), but their EICAT impact is listed as Data Deficient (Evans et al. 2016).

\subsubsection{African Sacred Ibis, Threskiornis aethiopicus}

African Sacred Ibis were introduced to Europe from Egypt (from where it later disappeared) in the 1700s, and small populations were maintained until the 1970s when they became popular exhibits in zoological gardens (Clergeau et al. 2010). A zoo in Brittany was the origin of the northern French invasive population, which had reached 3000 individuals by 2004 (Marion 2013). Similarly, another zoo on the Mediterranean coast was the source of a population there, which was said to have potential predatory impacts on threatened native birds. This prompted a nationwide call for their extermination, and caused conflict with people who argued for their aesthetic quality. Marion (2013) argued that as their principle diet is of invertebrates, they are not the predatory threat that others had claimed (see also Strubbe et al. 2011), although they are opportunistic predators of birds, reptiles, fish and amphibians. 
Escapes from zoos also occurred in Spain, the Canary Islands, and Italy, but in these locations numbers have not exceeded efforts to control and contain them (Yesou and Clergeau 2005). Small populations of African Sacred Ibis also occur in United Arab Emirates, Taiwan (Dayuan Township, Taoyuan City County) and the Florida Everglades (Yesou and Clergeau 2005). Evans et al. (2016) listed their EICAT impact is listed as Minor due to predation.

\subsubsection{Amphibians}

\subsubsection{The African Clawed Frog, Xenopus laevis}

African clawed frogs have been widely introduced to laboratories the world over since the 1930s, first for pregnancy testing, then as a model amphibian and most recently as a popular pet species (Box 27.1). Although these frogs are principally aquatic, they readily move between ponds up to distances of several kilometers (Measey 2016; de Villiers and Measey 2017), making their invasions like those of other amphibians and crayfish. Currently, they are known from multiple countries on four continents (Measey et al. 2012). Invasions are relatively well studied in Italy (Sicily: Lillo et al. 2008; Giacalone et al. 2008), Chile (Lobos and Measey 2002; Lobos and Jaksic 2005; Lobos et al. 2013), Portugal (Rebelo et al. 2010; Moreira et al. 2017), UK (Measey and Tinsley 1998; Measey 1998, 2001) and USA (McCoid and Fritts 1980a, b, 1989). Adults are principally predators of aquatic macroinvertebrates (Measey 1998; Amaral and Rebelo 2012; Courant et al. 2017c, 2018a), but there is evidence that they adversely affect native amphibian populations in their introduced areas (Lillo et al. 2011; Courant et al. 2018). Indeed, adults are capable of ingesting a range of vertebrate prey items (Lafferty and Page 1997; Measey et al. 2015). African clawed frogs are assessed as having Major impacts (Kumschick et al. 2017; Measey et al. 2016) using the EICAT scheme. Adults also carry parasites, but invasive populations generally have a reduced parasite diversity (Schoeman et al. 2019). Little work has been carried out on tadpoles, although they were found to respond to novel and historical predators in a similar fashion (Kruger et al. 2019).

The French invasion is noteworthy as it has a higher genetic diversity than any known native site, originating from two genetic clades native to southern Africa (de Busschere et al. 2016). The mixing of these genetic lineages is suggested to be the reason for this population extending beyond the native niche, shifting its realised niche (Rödder et al. 2017). This suggests that in France the mixed lineages have adapted to local conditions and are no longer constrained by its historical niche. This population has already reached the Loire Valley (Louppe et al. 2017), a virtual gateway connecting waterways throughout mainland Europe and more than one million $\mathrm{km}^{2}$ of suitable climate space (Measey et al. 2012). Moreover, this estimate is set to increase given climate change scenarios, especially into north-western Europe (Ihlow et al. 2016). Despite the French invasion only being 40 years old, 
this invasion shows many attributes of a population undergoing evolution through spatial sorting (see Box 27.2).

It has been suggested that this species shows an invasion debt of $\sim 15$ years (van Sittert and Measey 2016), and with high propagule pressure continuing in the form of shipments for pets (Measey 2017). This species has many traits which appear universally favoured (Measey et al. 2020, Chap. 5). It seems likely that we will continue to see many more invasive populations the world over.

\subsubsection{The Guttural Toad, Sclerophrys gutturalis}

The Guttural Toad has a wide distribution in southern Africa, from Ethiopia across Uganda to northern Angola, and across much of Botswana, Zimbabwe, Mozambique and the north and east parts of South Africa (Telford et al. 2019). The first introduction of the Guttural Toad outside their native range was a naive attempt at bio-control for Cane Beetles, Phyllophaga smithi, in Mauritius in 1922. They were introduced by the director of the dock management company in Port Louis, Gabriel Regnard (Cheke and Hume 2010). It is noteworthy that after the failure of the Guttural Toad to control the Cane Beetle, Gabriel Regnard tried and failed to introduce the Cane Toad, Rhinella marina (from Puerto Rico), on several occasions (Cheke and Hume 2010). Although it is not recorded from where these Guttural Toads were sourced, a genetic study suggests that the most likely source is Durban, South Africa (Telford et al. 2019). Guttural Toads were moved from Mauritius to Reunion around 1927, again as a bio-control agent, but this time against malaria carrying mosquitoes (Cheke and Hume 2010). Following both introductions, these toads quickly colonised the lower areas of each island. They are thought to have a moderate (MO) impact by predation of native snails in Mauritius (Kumschick et al. 2017; Measey et al. 2016), although this is with low confidence as no study has quantified their diet. Guttural Toads are also invasive within South Africa (see Measey et al. 2020, Chap. 5).

\subsubsection{Clicking Stream Frog, Strongylopus grayii}

The Clicking Stream Frog is native to a wide area of South Africa across rainfall zones (cf. Fig. 13.2, Wilson et al. 2020, Chap. 13), where it forms two distinctive clades corresponding to summer and winter rainfall (Tolley et al. 2010). This species has long been known to have been introduced to St. Helena 200 years ago with the suggestion that it was imported as duck food (Basilewsky 1970). Little information exists about the extent and impacts of this invasive population, except that it is still present today (N. Terblanche pers. comm.). 


\subsubsection{Reptiles}

\subsubsection{The Nile Monitor, Varanus niloticus}

The introduction of the Nile Monitor to Florida, USA, dates back to at least 1990 (Campbell 2003; Enge et al. 2004), and now occupies an estimated area of $\sim 50 \mathrm{~km}^{2}$ of the freshwater canals, lakes and wetlands of Cape Coral (Campbell 2003). These animals were introduced through the pet trade, and likely released when they outgrew their owners (Enge et al. 2004). Impacts are anecdotal, but include predation on rabbits, goldfish and potentially feral cats (Campbell 2003). Stomach contents revealed aquatic and terrestrial vertebrates and invertebrates, including clutches of reptile and bird eggs and an adult Florida Burrowing Owl, Athene cunicularia (Campbell 2005). It is estimated that the population is in excess of 1000 individuals, and expanding onto nearby islands and along the coast (Campbell 2005).

\subsubsection{The Tropical House Gecko, Hemidactylus mabouia}

The Tropical House Gecko is endemic to a large part of central and East Africa, and its distribution extends into the northeast of South Africa. Kluge (1969) notes that the first record of $H$. mabouia outside Africa is in the Lesser Antilles in 1654. The distribution of invasive populations of Tropical House Geckos has recently been reviewed (Weterings and Vetter 2017), and includes much of South America, the Caribbean and North America, as well as scattered tropical islands. It is noteworthy that this species is successfully established outside of its native range within South Africa, another domestic exotic (see Measey et al. 2020, Chap. 5). It is still unknown whether any of the invasive populations originate from South Africa, or elsewhere in their distribution, although it seems plausible that some populations may have originated from South African ports such as Durban. Genetic analyses of populations in Florida (with samples from South America and Africa) suggest that it is unlikely that these introductions resulted from multiple source localities in Africa (Short and Petren 2011), instead suggesting that South America has acted as a bridgehead for other Caribbean and North American invasions. House geckos, and their eggs, are accidentally distributed by humans, having been moved long distances by cars (Norval et al. 2012). In their invaded range, they have been found to have near total overlap with other geckos exploiting the same anthropogenic niche (e.g. Short and Petren 2012).

\subsubsection{Cape Dwarf Chameleon, Bradypodion pumilum}

The Cape Dwarf Chameleon is restricted to a small area in the extreme southwest of Africa, where it inhabits both forest and fynbos habitats, although it has successfully moved into periurban areas around Cape Town and Stellenbosch, including 
vineyards (Tolley and Burger 2012; Tolley and Measey 2007) where it is considered Near Threatened by the IUCN. Established populations were recorded in periurban gardens of Walvis Bay and Swakopmund in Namibia, and are presumed to have been deliberately introduced from gardens around Cape Town (Griffin 2000). These Walvis Bay populations were still present in 2004 (Bethune et al. 2004), but it could not be ascertained whether these populations, or another introduction to Luderitz (Griffin 2000) are extant.

\subsubsection{Fish}

\subsubsection{Indo-Pacific Lionfish, Pterois volitans and P. miles}

Although lionfish invasions were first ascribed to the Red Lionfish, Pterois volitans, genetic studies revealed a co-invasion by the Devil Firefish P. miles (Freshwater et al. 2009). As these species are difficult to distinguish in the field, most studies simply consider them as a single Indo-Pacific Lionfish invasion. Native to the IndoPacific region, including the East coast of South Africa, these were the first non-native marine fishes to establish in the Western North Atlantic (Schofield 2009). Although sporadic sightings were made for a decade before, it was only after 2000 that Lionfish increased in abundance and spread within the Western North Atlantic (Schofield 2009). Presently, invasions are recognised from the Caribbean Sea, the USA, the Mediterranean Sea, Netherlands and Venezuela (Schofield 2009, 2010; World Registry of Marine Species 2019). The invasion of the USA and ultimately the Caribbean is thought to be linked to the release of six individuals from an aquarium in south Florida when it was damaged during Hurricane Andrew in 1992 (Courtenay 1995). These invasive predators alter coral-reef ecosystems through predation of invertebrates and native fishes and competition with native predators. In fact, studies have demonstrated a decline of almost $80 \%$ in native fish recruitment in the presence of Lionfish (Albins and Hixon 2008).

\subsubsection{Chubbyhead Barb, Enteromius anoplus}

The Chubbyhead Barb is a resident in most catchments in South Africa (but absent from arid northwestern areas: from the Berg and Breede Rivers as well as the coastal rivers of the south-west and south Cape and the lower Orange River), and southern Mozambique (Skelton 2001). This species is thought to have been introduced to the Kuiseb system in central coastal Namibia (de Moor and Bruton 1988; Bethune et al. 2004). Dixon and Blom (1974) suggested that populations were introduced to the river pools of the Gaub (part of the Kuiseb system) by local farmers with stocks from the Orange or Olifants River in the South African Cape. Records show that E. anoplus was established in the late 1960s, but the current status of this population 
is unknown. It is also possible that this population is not alien but that this isolated Namibian population is part of its natural range (P. Skelton pers. comm.).

\subsubsection{African Sharp Toothed Catfish, Clarias gariepinus}

Clarias gariepinus (Sharptooth catfish) is native to most of Africa and some parts of western Asia (Lebanon, Israel, and Turkey) (Skelton 2001). It is one of the most widely distributed fish on the African continent, with a native range that extends from the Nile in the north to as far south as the Orange system in South Africa. It has been introduced widely around the world, mainly to countries in Asia and a few countries in Africa, Europe, and South America (CABI 2019; Froese and Pauly 2019). The origin of most global introductions are not well documented, but include African countries, bridgehead introductions from Europe to Asia, and Asian countries (Froese and Pauly 2019).

Most introductions of the African Sharp Toothed Catfish have been for aquaculture, with some introductions facilitated by inter basin-transfer schemes and by direct stocking (Weyl et al. 2016, 2020, Chap. 6; Faulkner et al. 2020, Chap. 12, Box 22.2). The species is well suited for aquaculture because it can tolerate extreme environmental conditions such as low oxygen, high turbidity and desiccation (Donnelly 1973; Bruton 1979a). It also has favourable life-history traits such as early maturity, fast growth rate and good food conversion ratios (Na-Nakorn and Brummett 2009). These life history traits have also predisposed it to successful establishment in areas of introduction (Weyl et al. 2016).

Clarias gariepinus has a wide variety of prey that includes algae, macrophytes, invertebrates and vertebrates (Bruton 1979b). This wide trophic niche also implies that it can cause strong alterations at multiple trophic levels of invaded ecosystems through mechanisms such as predation and herbivory/grazing (e.g. Cambray et al. 2003; Vitule et al. 2006; Kadye and Booth 2012; Alexander et al. 2014).

\subsubsection{Mozambique Tilapia, Oreochromis mossambicus}

Oreochromis mossambicus (Mozambique Tilapia) is native to east flowing rivers in central and southern Africa. Its natural range extends from the lower Zambezi system in Mozambique to the Bushmans system in South Africa, extending far inland within the Limpopo River Basin, but south of the Pongola River system, it is naturally confined to coastal areas (Skelton 2001). The provenance of populations in Namibia is unknown (Dixon and Blom 1974). Oreochromis mossambicus is regarded as one of the most widely introduced fish species globally, and has been reported to have been introduced and is present in over 50 countries (Pullin et al. 1997; Froese and Pauly 2019). Early introduction records of $O$. mossambicus indicate that it was first introduced to the island of Java in Indonesia prior to 1930. Subsequent introductions have occurred all over the world mainly as bridgehead invasions from initial areas of 
introductions (see Sect. 27.3.5). A large proportion of these introductions occurred within countries in Asia and Central America and the Caribbean.

Mozambique Tilapia has been widely distributed around the world for aquaculture and biological control of aquatic insects and macrophytes (Pullin et al. 1997; Froese and Pauly 2019). It is well-suited for aquaculture because it is easy to breed in captivity and it can tolerate a wide range of environmental conditions (Philippart and Ruwet 1982; Trewavas 1983). These adaptive life history characteristics have enabled it to occupy many different tropical and sub-tropical freshwater and estuarine niches in areas of introduction (Pullin et al. 1997). However, since the mid-1980s, there was a shift in producer preferences away from the O. mossambicus towards culturing of O. niloticus (Nile tilapia), which has a higher growth rate and reduced tendency to stunt (Pullin 1988).

Oreochromis mossambicus has been implicated in causing adverse environmental effects in areas of introduction (Canonico et al. 2005; Russell et al. 2012). Examples include competitive displacement of native species (e.g., Pérez et al. 2006), habitat alteration through herbivory (e.g., Doupé et al. 2010) and predation (de Silva et al. 1984). Despite these negative environmental effects, the introduction of O. mossambicus has in some cases (e.g. in Sri Lanka, Indonesia and Philippines), led to pronounced fisheries production and poverty alleviation by creating alternative aquaculture and fisheries livelihoods (de Silva et al. 2004). Although Mozambique Tilapia is considered invasive in most areas of introduction, in its natural range it is considered Endangered due to hybridisation with another introduced tilapia, O. niloticus (Firmat et al. 2013).

\subsubsection{Invertebrates}

Picker and Griffiths (2011) listed both the Big-headed Ant, Pheidole megacephala, and the Four-tone Nudibranch, Godiva quadricolor, as native to South Africa. However, other workers suggest that $P$. megacephala was originally from Cameroon or the northern part of sub-Saharan Africa. Wheeler (1922) concluded: "In all probability Pheidole megacephala is of Ethiopian or Malagasy origin, as it shows a great development of subspecies and varieties in these two regions and nowhere else." Wetterer (2012), could find no subsequent study that questions this conclusion, including a genetic study by Moreau (2008) which suggested that it was most closely related to species from Madagascar and Ghana. Slingsby (2017) lists this species as being invasive in southern Africa (see Janion-Scheepers and Griffiths 2020, Chap. 7). Today, P. megacephala is present throughout South Africa, and it seems likely that South African invasions have played a bridgehead effect in the distribution of this species through some of its invasive range, as has been seen with other invertebrates (see Sect. 27.3.3.1). Similarly, Cervera et al. (2010) note that G. quadricolor rarely occurs outside of the Indo-Pacific, suggesting that although this species was first described from temperate False Bay in south-western South Africa, it is more likely to represent an early invasion. 


\subsubsection{The Geranium Bronze Butterfly, Cacyreus marshalli}

The Geranium Bronze Butterfly, Cacyreus marshalli, is invasive in eastern Spain and the Mediterranean islands of Ibiza, Majorca and Menorca (Sarto i Monteys 1992). This species appears to be spreading rapidly in Europe: Crete (Anastassiu et al. 2010), Capania (northern Italy: Pignataro et al. 2006), the Balkan peninsula (Marko and Verovnik 2009), Republic of Northern Macedonia (Micevski and Micevski 2017) and in Egypt (Fric et al. 2014). Moreover, the risk of further spread of this species in Europe has been suggested, together with economic impacts to the horticultural trade, particularly against geraniums and pelargoniums (Quacchia et al. 2008). Sightings of this species have now been made throughout the Canary Islands and on Reunion (iNaturalist, accessed May 2019).

\subsubsection{South African Mantis, Miomantis caffra}

This praying mantis was first recorded in Auckland, New Zealand in 1978 (Ramsay 1990), from where it has spread throughout North Island, Nelson, and has recently been found in Christchurch (Fea et al. 2013). There is speculation that this species was introduced and has been moved around by accidental transport of the ootheca (egg masses), which can be adhered to crates. Brockerhoff et al. (2010) suggested that this mantis is a predator of native invertebrates and may compete directly with the native New Zealand mantis, Orthodera novaezealandiae, which is now thought be in decline as $M$. caffra is more aggressive, longer lived, and has more offspring (Ramsay 1990; Buckley et al. 2014). Moreover, native male O. novaezealandiae are more attracted to the scent of the invading $M$. caffra which respond by preying on the natives (Fea et al. 2014). Marabuto (2014) recorded this same mantis from Vila Sol, Faro, in the south of Portugal in August 2014. It is not known whether this is a second invasion from southern Africa or a secondary invasion from New Zealand. Records on iNaturalist (accessed May 2019) suggests that $M$. caffra has recently established in both Sydney and Melbourne, Australia.

\subsubsection{Brown Widow Spider, Latrodectus geometricus}

The Brown Widow Spider is distributed globally, with known invasive populations in North and South America, Hawaii and across Australasia. The small amount of genetic diversity globally, and the sister taxon being the southern African L. rhodesianus suggest a recent expansion from Africa (Garb et al. 2004), although it is not known whether the South American distribution has been anthropogenically facilitated. The distinctive spikey egg sacs adhere to outdoor objects (such as plant pots), and therefore are easily transported accidentally. Currently, it is not understood whether known invasive populations were introductions from South Africa. Bites from this spider can be medically important, although most cases appear not to 
warrant medical attention (Müller 1993). Within its invasive distribution, this species is strongly associated with domestic habitats in peri-urban environments (Vetter et al. 2012b), which means that it often comes into contact with people and therefore has a high chance of being moved around. There are reports that Brown Widows displace Black Widows, L. hesperus (Bianchi 1945; Baerg 1954), although this displacement may not be through competition but from enemy release from egg predation and parasitism (Vetter et al. 2012a). As the former bite less frequently and are less toxic it is thought that this displacement is of benefit to people (Vetter et al. 2012b).

\subsubsection{Brown Mussel, Perna perna}

Although originally described with a wider native distribution, the intertidal mussel Perna perna is now accepted as naturally occurring along the coasts of South Africa, Namibia, Angola, Mozambique, Madagascar and India (Berry 1978; Souza et al. 2003). While there has been some contention about its status in Brazil, the absence of shells from hunter-gatherer middens is now accepted as evidence that this mussel is not native to South America (Souza et al. 2003). This mussel is also alien in the Mediterranean Sea having arrived sometime before the 1970s (Berry 1978; Ahyong et al. 2019). Most recently, P. perna has invaded the Caribbean and the Gulf of Mexico (Hicks and Tunnell 1993). It is likely that shipping is the pathway of introduction for this species (Hicks et al. 2001), with hull fouling the likely vector. Although the ecological impacts of this mussel have not been quantified in its invaded range these mussels act as ecosystem engineers, offering habitat and protection to infaunal biota on the South Africa shoreline (Hammond and Griffiths 2006). Thus, if the mussel becomes dominant in an area that previously supported few mussels it could increase abundance and diversity of associated infauna (Sadchatheeswaran et al. 2015). Economic impacts have been associated with the invasion in the Gulf of Mexico where the species is considered to pose a risk to shipping safety as it can sink navigation buoys (Hicks and Tunnell 1995). It is also known to colonise jetties, petroleum platforms, wrecks and other artificial hard substrata (Hicks and Tunnell 1995). While this species can bring with it economic benefits from culturing (Ferreira et al. 2006), it concurrently poses a threat to human health as it can be affected by paralytic shellfish poisoning (Barbera-Sanchez et al. 2004).

\subsubsection{Shell-Boring Polychaete, Terebrasabella heterouncinata}

This marine tube-dwelling worm originates from the coast of South Africa (Fitzhugh and Rouse 1999). It was noted in California in 1993 after being unintentionally imported along with South African abalone (Kuris and Culver 1999). It has since spread to Mexico and Chile (Kuris and Culver 1999; Moreno et al. 2006). Terebrasabella heterouncinata is considered a pest as it causes shell abnormalities when boring into commercially important abalone (Fitzhugh and Rouse 1999). It 
escaped into the wild at one site in California, infecting native gastropods in high numbers (Culver and Kuris 2004). However, an intensive and prolonged management programme saw this aggressive invader extirpated from this location (Culver and Kuris 2000) and its prevalence reduced in farms.

\subsubsection{Spionid Worm, Boccardia pseudonatrix}

A native to the South African coast (Simon et al. 2010), this shell-boring polychaete has spread to Australia, New Zealand and Japan (Walker 2014; Abe et al. 2019). While B. pseudonatrix was first reported on farmed oysters in Australia in 2014, examination of preserved specimens revealed its earlier presence in New Zealand. As oysters have never been imported to Australia from South Africa, it is thought that the Australian occurrence represents natural spread from the introduced range in New Zealand (Walker 2014). The pathway of introduction to Japan is yet to be established. Although the impacts of this species have not been explicitly measured in its introduced range, the fact that this species impacts oyster and abalone culture and infests wild oysters in South Africa (Simon et al. 2010; Boonzaaier et al. 2014) suggests that it is likely to have similar consequences in its introduced range.

\subsection{Conclusions}

Compared to the large number of alien plant species originating from South Africa (Pyšek et al. 2020, Chap. 26), the number of alien animals has been small. If, as we speculate, the hiatus in trade relations between South Africa and the rest of the world led to the low number of donations recorded here, it could be that there is a significant invasion debt (Rouget et al. 2016). We suggest that candidate species which could be added to watch lists are those that are already domestic exotics within South Africa. South Africa also plays an important role in bridgehead effects, and this could be set to increase if it continues to act as a major commercial hub, especially for alien pets.

Acknowledgements We would like to thank the many colleagues who provided information on invasive and established populations elsewhere in the world. In particular Francois Becker, Roger Bills, Audrey Cook, Rohan Clarke, Whitney Gann, Clinton Hay, Graham Kerley, Steve Lange, Rob Simmons, Paul Skelton, Krystal Tolley, Nass Terblanche, Denis Tweedle, Brian van Wilgen and Olaf Weyl. We thank John Wilson, who made substantial suggestions for restructuring the chapter and the three reviewers of this chapter, Rui Rebelo, Fabian Jaksic and Phil Cassey. We would also like to thank the curators of the many databases that we consulted. JM, TR, NK and TZ would like to thank the DSI-NRF Centre of Excellence for Invasion Biology. TAZ also acknowledges the South African National Research Foundation (Grant 103602) for support. BH would like to thank the DSI-NRF Centre of Excellence in Tree Health Biotechnology, and members of the Tree Protection Cooperative Programme (TPCP). The South African Department of Environment, Forestry, and Fisheries (DEFF) are thanked for funding the South African National Biodiversity Institute noting that this publication does not necessarily represent the views or opinions of DEFF or its employees. 


\section{Electronic Supplementary Material}

The online version of this chapter (https://doi.org/10.5281/zenodo.3559957) contains supplementary material, which is available to authorised users.

\section{References}

Abe H, Takeuchi T, Taru M, Sato-Okoshi W, Okoshi K (2019) Habitat availability determines distribution patterns of spionid polychaetes (Annelida: Spionidae) around Tokyo Bay. Mar Biodivers Rec 12:7. https://doi.org/10.1186/s41200-019-0167-4

Ahyong S, Costello MJ, Galil BS, Gollasch S, Hutchings P, Katsanevakis S, Lejeusne C, Marchini A, Occhipinti A, Pagad S, Poore GCB, Rius M, Robinson TB, Sterrer W, Turon X, Willan RC, Zhan A (2019) World Register of Introduced Marine Species (WRiMS). Perna perna (Linnaeus, 1758). http://www.marinespecies.org/introduced/aphia.php? $\mathrm{p}=$ taxdetails\& id=140483 on 2019-04-01. Accessed 29 Mar 2018

Albins MA, Hixon MA (2008) Invasive Indo-Pacific lionfish (Pterois volitans) reduce recruitment of Atlantic coral reef fishes. Mar Ecol Prog Ser 367:233-238. https://doi.org/10.3354/ meps07620

Alexander ME, Dick JTA, Weyl OLF, Robinson TB, Richardson DM (2014) Existing and emerging high impact invasive species are characterised by higher functional responses than natives. Biol Lett 10:20130946. https://doi.org/10.1098/rsbl.2013.0946

Alford RA, Brown GP, Schwarzkopf L, Phillips BL, Shine R (2009) Comparisons through time and space suggest rapid evolution of dispersal behaviour in an invasive species. Wildl Res 36:23-28. https://doi.org/10.1071/WR08021

Amaral P, Rebelo R (2012) Diet of invasive clawed frog Xenopus laevis at Lage stream (Oeiras, W Portugal). Herpetol J 22(3):187-190

Amundsen PA, Salonen E, Niva T et al (2012) Invader population speeds up life-history during colonization. Biol Invasions 14:1501-1513. https://doi.org/10.1007/s10530-012-0175-3

Anastassiu HT, Ghavalas N, Coutsis JG (2010) First record of Cacyreus marshalli in Greece, and comments on the potential occurrence of Zizeeria karsandra on the Greek island of Crete (Lepidoptera: Lycaenidae). Phegea 38(3):85-92

Baerg WJ (1954) The brown widow and the black widow spiders in Jamaica (Araneae, Theridiidae). Ann Entomol Soc Am 47(1):52-60. https://doi.org/10.1093/aesa/47.1.52

Barbera-Sanchez A, Soler JF, Astudillo LR, Chang-Yen I (2004) Paralytic shellfish poisoning (PSP) in Margarita Island, Venezuela. Rev Biol Trop 52(Suppl 1):89-98

Barré N (1983) Distribution et abondance des oiseaux terrestres de lîle de la Réunion (Océan Indien). Rev Écol 37:37-85

Basilewsky P (1970) La fauna terrestre de l'île de Sainte-Hélène, première partie: Vertébrés. Annales de Sciences Zoologiques de Musee Royal de L'Afrique Centrale 181:77-132

Bell-Cross G, Minshull JL (1988) The fishes of Zimbabwe. National Museums and Monuments of Zimbabwe, Bulawayo

Bender LC, Li H, Thompson BC, Morrow PC, Valdez R (2003) Infectious disease survey of gemsbok in New Mexico. J Wildl Dis 39(4):772-778. https://doi.org/10.7589/0090-3558-39.4. 772

Berry PF (1978) Reproduction, growth and production in the mussel, Perna perna (Linnaeus), on the east coast of South Africa. South African Association for Marine Biological Research Oceanographic Research Institute Investigational Report No. 48

Bethune S, Griffin M, Joubert DF (2004) National review of invasive alien species, Namibia. Ministry of Environment and Tourism, Windhoek 
Bianchi FA (1945) Notes on the, Abundance of the spiders Latrodectus mactans, L. geometricus and Argiope avara, and of their Parasites. Proc Hawaiian Entomol Soc 12(2):245-247

Blackburn TM, Duncan RP (2001) Establishment patterns of exotic birds are constrained by non-random patterns in introduction. J Biogeogr 28:927-939. https://doi.org/10.1046/j.13652699.2001.00597.x

Blench R (2008) The Austronesians in Madagascar and their interaction with the Bantu of the East African coast: surveying the linguistic evidence for domestic and translocated animals. Stud Philipp Lang Cult 18:18-43

Bonte D, Dyck HV, Bullock JM, Coulon A, Delgado M, Gribbs M, Lehouck V, Matthysen E, Mustin K, Saastamoinen M et al (2012) Costs of dispersal. Biol Rev 87:290-312. https://doi. org/10.1111/j.1469-185X.2011.00201.x

Boonzaaier MK, Neethling S, Mouton A, Simon CA (2014) Polydorid polychaetes (Spionidae) on farmed and wild abalone (Haliotis midae) in South Africa: an epidemiological survey. Afr J Mar Sci 36:369-376. https://doi.org/10.2989/1814232X.2014.952249

Brazil M (2009) Birds of East Asia: eastern China, Taiwan, Korea, Japan, eastern Russia. Christopher Helm, London

Brockerhoff EG, Barratt BI, Beggs JR, Fagan LL, Malcolm K, Phillips CB, Vink CJ (2010) Impacts of exotic invertebrates on New Zealand's indigenous species and ecosystems. N Z J Ecol 34 (1): 158

Brooke RK, Siegfried WR (1991) Birds introduced to the fynbos biome of South Africa. In: Groves RH, di Castri F (eds) Biogeography of Mediterranean invasions. Cambridge University Press, Cambridge, p 359. https://doi.org/10.1017/CBO9780511525544.027

Brooke RK, Lockwood JL, Moulton MP (1995) Patterns of success in passeriform bird introductions on Saint Helena. Oecologia 103(3):337-342. https://doi.org/10.1007/BF00328622

Brown GP, Kelehear C, Shine R (2013) The early toad gets the worm: cane toads at an invasion front benefit from higher prey availability. J Anim Ecol 82:854-862. https://doi.org/10.1111/ $1365-2656.12048$

Bruton MN (1979a) The survival of habitat desiccation by air-breathing clariid catfishes. Environ Biol Fish 4:273-280. https://doi.org/10.1007/BF00005484

Bruton MN (1979b) The food and feeding behaviour of Clarias gariepinus (Pisces: Clariidae) in Lake Sibaya, South Africa, with emphasis on its role as a predator of cichlids. Tran Zool Soc Lond 35:47-114. https://doi.org/10.1111/j.1096-3642.1979.tb00057.x

Buckley TR, Palma RL, Johns PM, Gleeson DM, Heath ACG, Hitchmough RA, Marabuto E (2014) The Afrotropical Miomantis caffra Saussure 1871 and Miomantis paykullii Stal 1871: first records of alien mantid species in Portugal and Europe, with an updated checklist of Mantodea in Portugal (Insecta: Mantodea). Biodivers Data J (2):e4117. https://doi.org/10.3897/BDJ.2. e4117

Buriticá SM (2014) Los hipopótamos (Hippopotamus amphibius) en Colombia. Especie exótica, introducida e invasora. Rev Lasallista Investig 11:229-230

Burton OJ, Phillips BL, Travis JMJ (2010) Trade-offs and the evolutions of life-histories during range expansion. Ecol Lett 13:1210-1220. https://doi.org/10.1111/j.1461-0248.2010.01505.x

CABI (2019) Clarias gariepinus [original text by Wing-Keong Ng]. In: Invasive species compendium. Wallingford: $\mathrm{CAB}$ International. www.cabi.org/isc

Cain JW, Avery MM, Caldwell CA, Abbott LB, Holechek JL (2017) Diet composition, quality and overlap of sympatric American pronghorn and gemsbok. Wildl Biol 2017(4). https://doi.org/10. 2981/wlb.00296

Callaghan CT, Brooks DM (2016) Ecology, behavior, and reproduction of invasive Egyptian geese (Alopochen aegyptiaca) in Texas. Bull Tex Ornithol Soc 49(1-2):37-45

Cambray JA (2003) The need for research and monitoring on the impacts of translocated sharptooth catfish, Clarias gariepinus, in South Africa. Afr J Aquat Sci 28:191-195. https://doi.org/10. 2989/16085910309503786

Campbell TS (2003) Species profile: Nile monitors (Varanus niloticus) in Florida. Iguana 10 (4):119-120 
Campbell TS (2005) Eradication of introduced carnivorous lizards from the Cape Coral area. Final Report to the Charlotte Harbor National Estuary Program, 1926 Victoria Avenue, Ft. Myers, FL 3390130

Canonico GC, Arthington A, McCrary JK, Thieme ML (2005) The effects of introduced tilapias on native biodiversity. Aquat Conserv Mar Freshwat Ecosyst 15:463-483. https://doi.org/10.1002/ aqc. 699

Cardoso GC, Reino L (2018) Ecologically benign invasions: the invasion and adaptation of common waxbills (Estrilda astrild) in iberia. In: Queiroz AI, Pooley S (eds) Histories of bioinvasions in the Mediterranean. Springer Nature, pp 149-169. https://doi.org/10.1007/9783-319-74986-0_7

Carrete M, Tella J (2008) Wild-bird trade and exotic invasions: a new link of conservation concern? Front Ecol Environ 6(4):207-211. https://doi.org/10.1890/070075

Cervera JL, Tamsouri N, Moukrim A, Villani G (2010) New records of two alien opisthobranch molluscs from the north-eastern Atlantic: Polycera hedgpethi and Godiva quadricolor. Mar Biodivers Rec 3:e51. https://doi.org/10.1017/S1755267210000102

Cheke A, Hume JP (2010) Lost land of the dodo: the ecological history of Mauritius, Réunion and Rodrigues. Bloomsbury Publishing

Chuang A, Peterson CR (2016) Expanding population edges: theories, traits, and trade-offs. Glob Chang Biol 22:494-512. https://doi.org/10.1111/gcb.13107

Clergeau P, Fourcy D, Reeber S, Yesou P (2010) New but nice? Do alien sacred ibises Threskiornis aethiopicus stabilize nesting colonies of native spoonbills Platalea leucorodia at Grand-Lieu Lake, France? Oryx 44(4):533-538. https://doi.org/10.1017/S0030605310001006

Courant J, Secondi J, Bereiziat V, Herrel A (2017a) Resources allocated to reproduction decrease at the range edge of an expanding population of an invasive amphibian. Biol J Linn Soc 122:157-165. https://doi.org/10.1093/biolinnean/blx048

Courant J, Vogt S, Marques R, Measey J, Secondi J, Rebelo R, de Villiers A, Ihlow F, De Busschere C, Backeljau T, Rödder D, Herrel A (2017c) Are invasive populations characterized by a broader diet than native populations? PeerJ 5:e3250. https://doi.org/10.7717/peerj.3250

Courant J, Secondi J, Vollette J, Herrel A, Thirion J-M (2018) Assessing the role of an invasive anuran on a diverse amphibian community. Amphibia-Reptilia 39:203-218. https://doi.org/10. $1163 / 15685381-17000153$

Courant J, Vollette E, Herrel A (2018a) Changes in the aquatic macro-invertebrate communities through the expanding range of an invasive anuran. Food Webs J 17:e00098. https://doi.org/10. 1016/j.fooweb.2018.e00098

Courant J, Adil L, De Kegel B, Adriaens D, Herrel A (2019a) Conserved growth rate and age structure of Xenopus laevis in the edge and core of an expanding population. Biol J Linn Soc 128(1):122-129. https://doi.org/10.1093/biolinnean/blz088

Courant J, Secondi J, Guillemet L, Vollette E, Herrel A (2019b) Rapid changes in dispersal on a small spatial scale at the range edge of an expanding population. Evol Ecol 33(4):599-612. https://doi.org/10.1007/s10682-019-09996-x

Courtenay WR (1995) Marine fish introductions in southeastern Florida. Am Fish Soc Introduc Fish Sect Newsl 14:2-3

Crystal-Ornelas R, Lockwood JL, Cassey P, Hauber ME (2017) The establishment threat of the obligate brood-parasitic Pin-tailed Whydah (Vidua macroura) in North America and the Antilles. Condor 119(3):449-458. https://doi.org/10.1650/CONDOR-16-150.1

Culver CS, Kuris AM (2000) The apparent eradication of a locally established introduced marine pest. Biol Invasions 2:245-253. https://doi.org/10.1023/A:1010082407254

Culver CS, Kuris AM (2004) Susceptibility of California gastropods to an introduced South African sabellid polychaete, Terebrasabella heterouncinata. Invertebr Biol 123(4):316-323. https://doi. org/10.1111/j.1744-7410.2004.tb00165.x

Cwynar LC, MacDonald GM (1987) Geographical variation of lodgepole pine in relation to population history. Am Nat 129(3):463-469. https://doi.org/10.1086/284651

DAISIE (2019) European Invasive Alien Species Gateway. http://www.europe-aliens.org 
Davies SJ, Jordaan M, Karsten M et al (2020) Experience and lessons from alien and invasive animal control projects in South Africa. In: van Wilgen BW, Measey J, Richardson DM, Wilson JR, Zengeya TA (eds) Biological invasions in South Africa. Springer, Berlin, pp 625-660. https://doi.org/10.1007/978-3-030-32394-3_22

De Busschere C, Courant J, Herrel A, Rebelo R, Rödder D, Measey GJ, Backeljau T (2016) Unequal contribution of native South African phylogeographic lineages to the invasion of the African clawed frog, Xenopus laevis, in Europe. PeerJ 4:e1659. https://doi.org/10.7717/peerj. 1659

de Moor IJ, Bruton MN (1988) Atlas of alien and translocated indigenous aquatic animals in southern Africa. South African National Scientific Programmes Report 144

De Silva SS, Perera MK, Maitipe P (1984) The composition, nutritional status and digestibility of the diets of Sarotherodon mossambicus from nine man-made lakes in Sri Lanka. Environ Biol Fish 11:205-219. https://doi.org/10.1007/BF00000465

De Silva SS, Subasinghe RP, Bartley DM, Lowther A (2004) Tilapias as alien aquatics in Asia and the Pacific: a review. FAO Fisheries Technical Paper No. 453. FAO, Rome

De Villiers FA, Measey J (2017) Overland movement in African clawed frogs (Xenopus laevis): empirical dispersal data from within their native range. PeerJ $5:$ :4039. https://doi.org/10.7717/ peerj. 4039

de Jersey Gemmill D (2015) Birds of Vieques Island Puerto Rico: status, abundance, and conservation. Scholarly and Specialized Publishing

Dixon JEW, Blom MJ (1974) Some aquatic vertebrates from the Namib Desert, South West Africa. Modoqua 2(3):31-32

Donnelly BG (1973) Aspects of behaviour in the catfish Clarias gariepinus (Pisces: Clariidae) during periods of habitat desiccation. Arnoldia 6:1-8

Doupé RG, Knott MJ, Schaffer J, Burrows DW, Lymbery AJ (2010) Experimental herbivory of native Australian macrophytes by the introduced Mozambique tilapia Oreochromis mossambicus. Austral Ecol 35:24-30. https://doi.org/10.1111/j.1442-9993.2009.02008.x

Douthwaite RJ, Jones EW, Tyser AB, Vrdoljak SM (2018) The introduction, spread and ecology of redclaw crayfish Cherax quadricarinatus in the Zambezi catchment. Afr J Aquat Sci 43:353-366. https://doi.org/10.2989/16085914.2018.1517080

Duncan RP, Blackburn TM, Sol D (2003) The ecology of bird introductions. Annu Rev Ecol Syst 34:71-98. https://doi.org/10.1146/annurev.ecolsys.34.011802.132353

Dyer EE, Redding DW, Blackburn TM (2017) The global avian invasions atlas, a database of alien bird distributions worldwide. Sci Data 4:170041. https://doi.org/10.1038/sdata.2017.41

Eguchi K, Amano HE (2004) Spread of exotic birds in Japan. Ornithol Sci 3(1):3-11. https://doi. org/10.2326/osj.3.3

Ellender BR, Weyl OLF (2014) A review of current knowledge, risk and ecological impacts associated with non-native freshwater fish introductions in South Africa. Aquat Invasions 9:117-132. https://doi.org/10.3391/ai.2014.9.2.01

Enge KM, Krysko KL, Hankins KR, Campbell TS, King FW (2004) Status of the Nile monitor (Varanus niloticus) in southwestern Florida. Southeast Nat 3(4):571-583. https://doi.org/10. 1656/1528-7092(2004)003[0571:SOTNMV]2.0.CO;2

Evans T, Kumschick S, Blackburn TM (2016) Application of the Environmental Impact Classification for Alien Taxa (EICAT) to a global assessment of alien bird impacts. Divers Distrib 22 (9):919-931. https://doi.org/10.1111/ddi.12464

Evenett SJ (2002) The impact of economic sanctions on South African exports. Scott J Polit Econ 49(5):557-573. https://doi.org/10.1111/1467-9485.00248

Faulkner KT, Robertson MP, Rouget M, Wilson JR (2017a) Prioritising surveillance for alien organisms transported as stowaways on ships travelling to South Africa. PLoS One 12(4): e0173340. https://doi.org/10.1371/journal.pone.0173340

Faulkner KT, Hurley BP, Robertson MP, Rouget M, Wilson JRU (2017b) The balance of trade in alien species between South Africa and the rest of Africa. Bothalia 47:a2157. https://doi.org/10. 4102/abc.v47i2.2157 
Faulkner KT, Burness A, Byrne MJ et al (2020) South Africa's pathways of introduction and dispersal and how they have changed over time. In: van Wilgen BW, Measey J, Richardson DM, Wilson JR, Zengeya TA (eds) Biological invasions in South Africa. Springer, Berlin, pp 311352. https://doi.org/10.1007/978-3-030-32394-3_12

Fea MP, Stanley MC, Holwell GI (2013) Fatal attraction: sexually cannibalistic invaders attract naive native mantids. Biol Lett 9(6):20130746. https://doi.org/10.1098/rsbl.2013.0746

Fea MP, Stanley MC, Holwell GI (2014) Cannibalistic siblicide in praying mantis nymphs (Miomantis caffra). J Ethol 32(1):43-51. https://doi.org/10.1007/s10164-013-0391-Z

Federico G, Tena-Junguito A (2017) A tale of two globalizations: gains from trade and openness 1800-2010. Rev World Econ 153(3):601-626. https://doi.org/10.1007/s10290-017-0279-z

Ferreira JF, Besen K, Wormsbecher AG, dos Santos RF (2006) Physical-chemical parameters of seawater mollusc culture sites in Santa Catarina-Brazil. J Coast Res 39:1122-1126

Firmat C, Alibert P, Losseau M, Baroiller JF, Schliewen UK (2013) Successive invasion-mediated interspecific hybridizations and population structure in the endangered cichlid Oreochromis mossambicus. PLoS One 8:e63880. https://doi.org/10.1371/journal.pone.0063880

Fitzhugh K, Rouse GW (1999) A remarkable new genus and species of fan worm (Polychaeta: Sabellidae: Sabellinae) associated with marine gastropods. Invertebr Biol 118:357-390. https:// doi.org/10.2307/3227007

Forshaw J (2015) Pigeons and doves in Australia. CSIRO Publishing. https://doi.org/10.1071/ 9781486304042

Fouquet A, Measey GJ (2006) Plotting the course of an African clawed frog invasion in western France. Anim Biol 56:95-102. https://doi.org/10.1163/157075606775904722

Frahnert S, Román RA, Eckhoff P, Wiley JW (2015) Juan Cristóbal Gundlach's collections of Puerto Rican birds with special regard to types. Zoosyst Evol 91:177

Freshwater DW, Hamner RM, Parham S, Wilbur AE (2009) Molecular evidence that the lionfishes Pterois miles and Pterois volitans are distinct species. J N C Acad Sci 125:39-46. https://doi. org/10.3897/zse.91.5550

Fric Z, Dickinson R, Fetouh G, Larsen TB, Schön W, Wiemers M (2014) First record of the cycad blue, Chilades pandava, in Egypt - a new invasive butterfly species in the Mediterranean region and on the African continent (Lepidoptera: Lycaenidae). Afr Entomol 22:315-320. https://doi. org/10.4001/003.022.0205

Froese R, Pauly D (eds) (2019) FishBase. World Wide Web electronic publication. www.fishbase. org, version (02/2019)

Furman BL, Bewick AJ, Harrison TL, Greenbaum E, Gvoždík V, Kusamba C, Evans BJ (2015) Pan-African phylogeography of a model organism, the African clawed frog 'Xenopus laevis'. Mol Ecol 24(4):909-925. https://doi.org/10.1111/mec.13076

Ganzhorn JU, Fietz J, Rakotovao E, Schwab D, Zinner D (1999) Lemurs and the regeneration of dry deciduous forest in Madagascar. Cons Biol 13:794-804. https://doi.org/10.1046/j.1523-1739. 1999.98245.x

Garb JE, González A, Gillespie RG (2004) The black widow spider genus Latrodectus (Araneae: Theridiidae): phylogeny, biogeography, and invasion history. Mol Phylogenet Evol 31 (3):1127-1142. https://doi.org/10.1016/j.ympev.2003.10.012

Garrett JF, Garrett KL (2016) The Pin-tailed Whydah as a brood parasite of the Scaly-breasted Munia in southern California. Western Birds 47:314-320. https://doi.org/10.21199/WB47.4.4

Giacalone G, Valvo ML, Faraone FP, Lillo F (2008) The large invasive population of Xenopus laevis in Sicily, Italy. Amphibia-Reptilia 29(3):405-412. https://doi.org/10.1163/ 156853808785112075

Golden CD (2009) Bushmeat hunting and use in the Makira Forest, north-eastern Madagascar: a conservation and livelihoods issue. Oryx 43:386-392. https://doi.org/10.1017/ S0030605309000131

Graziosi I, Tembo M, Kuate J, Muchugi A (2019) Pests and diseases of trees in Africa: a growing continental emergency. Plants, People, Planet. https://doi.org/10.1002/ppp3.31

Greenlaw JS, Pranty B, Bowman R (2014) The Robertson and Woolfenden Florida bird species: an annotated list. Condor 117(4):685-686. https://doi.org/10.1650/CONDOR-15-114.1 
Griffin M (2000) The species diversity, distribution and conservation of Namibian reptiles: a review. Namibia Wissenschaftliche Gesellschaft 48:116-141

Guo Q, Ricklefs RE (2010) Domestic exotics and the perception of invasibility. Divers Distrib 16 (6):1034-1039. https://doi.org/10.1111/j.1472-4642.2010.00708.x

Gurdon JB, Hopwood N (2003) The introduction of Xenopus laevis into developmental biology: of empire, pregnancy testing and ribosomal genes. Int J Dev Biol 44(1):43-50

Gurdon JB, Elsdale TR, Fischberg M (1958) Sexually mature individuals of Xenopus laevis from the transplantation of single somatic nuclei. Nature 182(4627):64. https://doi.org/10.1038/ $182064 \mathrm{a} 0$

Gyimesi A, Lensink R (2012) Egyptian Goose Alopochen aegyptiaca: an introduced species spreading in and from the Netherlands. Wild 62(62):128-145

Hammond W, Griffiths CL (2006) Biogeographical patterns in the fauna associated with southern African mussels beds. Afr Zool 41:123-130. https://doi.org/10.1080/15627020.2006.11407342

Hastings MY, Farrell DJ (1991) A history of ostrich farming-its potential in Australian agriculture. Recent advances in Animal nutrition in Australia, 1991, pp 292-297

Hicks DW, Tunnell JW (1993) Invasion of the south Texas coast by the edible brown mussel Perna perna (Linnaeus, 1758). Veliger 36:92-94

Hicks DW, Tunnell JW (1995) Ecological notes and patterns of dispersal in the recently introduced mussel, Perna perna (Linne 1758), in the Gulf of Mexico. Am Malacol Bull 11:203-206

Hicks DW, Tunnell JW, McMahon RF (2001) Population dynamics of the nonindigenous brown mussel Perna perna in the Gulf of Mexico compared to other world-wide populations. Mar Ecol Prog Ser 211:181-192. https://doi.org/10.3354/meps211181

Hill JE, Lawson KM, Tuckett QM (2017) First record of a reproducing population of the African clawed frog Xenopus laevis Daudin, 1802 in Florida (USA). BioInvasions Record 6(1):87-94

Hill MP, Coetzee JA, Martin GD et al (2020) Invasive alien aquatic plants in South African freshwater ecosystems. In: van Wilgen BW, Measey J, Richardson DM, Wilson JR, Zengeya TA (eds) Biological invasions in South Africa. Springer, Berlin, pp 95-112. https://doi.org/10. 3391/bir.2017.6.1.14

Hogben L (1930) Some remarks on the relation of the pituitary gland to ovulation and skin secretion in Xenopus laevis. Proc R Soc S. Africa 22(pt. 2):xvii-xviii

Hudson CM, Phillips BL, Brown GP, Shine R (2015) Virgins at the vanguard: low reproductive frequency in invasion-front cane toads. Biol J Linn Soc 16:743-747. https://doi.org/10.1111/bij. 12618

Hughes CL, Dytham C, Hill JK (2007) Modelling and analysing evolution of dispersal in populations at expanding range boundaries. Ecol Entomol 32:437-445. https://doi.org/10. $1111 /$ j.1365-2311.2007.00890.x

Hulbert AJ, Else PL (1981) Comparison of the "mammal machine" and the "reptile machine": energy use and thyroid activity. Am J Phys 241:350-356. https://doi.org/10.1152/ajpregu.1981. 241.5.R350

Hurley BP, Garnas J, Wingfield MJ, Branco M, Richardson DM, Slippers B (2016) Increasing numbers and intercontinental spread of invasive insects on eucalypts. Biol Invasions 18:921-933. https://doi.org/10.1007/s10530-016-1081-x

Hurley BP, Slippers B, Sathyapala S, Wingfield MJ (2017) Challenges to planted forest health in developing economies. Biol Invasions 19:3273-3285. https://doi.org/10.1007/s10530-0171488-Z

Ihlow F, Courant J, Secondi J, Herrel A, Rebelo R, Measey GJ, Lillo F, de Villiers FA, Vogt S, De Busschere C, Backeljau T, Rödder D (2016) Impacts of climate change on the global invasion potential of the African clawed frog Xenopus laevis. PLoS One 11(6):e0154869. https://doi.org/ 10.1371/journal.pone. 0154869

Iwanicki I (1985) A desert harvest-Ostrich farming in South Australia. J Aust Stud 9(16):42-50. https://doi.org/10.1080/14443058509386902

Janion-Scheepers C, Griffiths CL (2020) Alien terrestrial invertebrates in South Africa. In: van Wilgen BW, Measey J, Richardson DM, Wilson JRU, van Wilgen BW (eds) Biological invasions in South Africa. Springer, Berlin, pp 183-204. https://doi.org/10.1007/978-3-03032394-3_7 
Jiménez-García MI, Vidal-Martínez VM, López-Jiménez S (2001) Monogeneans in introduced and native cichlids in Mexico: evidence for transfer. J Parasitol 87:907-909. https://doi.org/10.1645/ 0022-3395(2001)087[0907:MIIANC]2.0.CO;2

Jones CG (1996) Bird introductions 10 Mauritius: status and relationships with native birds. ln: Holmes JS, Simons JR (eds) The introduction and naturalisation of birds. HMSO, London, pp $113-123$.

Kadye WT, Booth AJ (2012) Integrating stomach content and stable isotope analyses to elucidate the feeding habits of non-native sharptooth catfish Clarias gariepinus. Biol Invasions 14:779-795. https://doi.org/10.1007/s10530-011-0116-6

Kampe-Persson H (2010) Occurrence of Egyptian Goose Alopochen aegyptiaca in Europe. Goose Bull 10:34-37

Karlsson B, Johansson A (2008) Seasonal polyphenism and developmental trade-offs between flight ability and egg laying in a pierid butterfly. Proc Biol Sci 275:2131-2136. https://doi.org/ $10.1098 / \mathrm{rspb} .2008 .0404$

Kluge AG (1969) The evolution and geographical origin of the New World Hemidactylus mebouiabrookii complex (Gekkonidae, Sauria). Misc Pub Mus Zool U Mich 138:1-78

Kraus F (2009) Alien reptiles and amphibians: a scientific compendium and analysis. Springer Science \& Business Media, New York. https://doi.org/10.1007/978-1-4020-8946-6

Kruger N, Measey J, Herrel A et al (2019) Anti-predator strategies of the invasive African clawed frog, Xenopus laevis, to native and invasive predators in western France. Aquat Invasions 14 (3):433-443. https://doi.org/10.3391/ai.2019.14.3.03

Krysko KL, Burgess JP, Rochford MR, Gillette CR, Cueva D, Enge KM, Somma LA, Stabile JL, Smith DC, Wasilewski JA, Kieckhefer GN III (2011) Verified non-indigenous amphibians and reptiles in Florida from 1863 through 2010: Outlining the invasion process and identifying invasion pathways and stages. Zootaxa 3028:1-64. https://doi.org/10.11646/zootaxa.3028.1.1

Kumschick S, Vimercati G, De Villiers FA et al (2017) Impact assessment with different scoring tools: How well do alien amphibian assessments match? Neobiota 33:53-66. https://doi.org/10. 3897/neobiota.33.10376

Kuris AM, Culver CS (1999) An introduced sabellid polychaete pest infesting cultured abalones and its potential spread to other California gastropods. Invertebr Biol 118:391-403. https://doi. org $/ 10.2307 / 3227008$

Lafferty KD, Page CJ (1997) Predation on the endangered tidewater goby, Eucyclogobius newberryi, by the introduced African clawed frog, Xenopus laevis, with notes on the frog's parasites. Copeia 1997(3):589-592. https://doi.org/10.2307/1447564

Lahti DC (2003) A case study of species assessment in invasion biology: the Village Weaverbird Ploceus cucullatus. Anim Biodivers Conserv 26(1):45-55

Le Roux JJ, Clusella-Trullas S, Mokotjomela TM et al (2020) Biotic interactions as mediators of biological invasions: insights from South Africa. In: van Wilgen BW, Measey J, Richardson DM, Wilson JR, Zengeya TA (eds) Biological invasions in South Africa. Springer, Berlin, pp 385-428. https://doi.org/10.1007/978-3-030-32394-3_14

Léotard G, Debout G, Dalecky A, Guillot S, Gaume L, McKey D, Kjellberg F (2009) Range expansion drives dispersal evolution in an Equatorial three-species symbiosis. PLoS One 4: e5377. https://doi.org/10.1371/journal.pone.0005377

Lever C (2005) Naturalised birds of the world. A\&C Black

Lillo F, Faraone FP, Valvo ML (2008) Xenopus laevis in Sicilia: areale, invasività e impatto. In Le specie alloctone in Italia: censimenti, invasività e piani di azione Milano 36:71-71

Lillo F, Faraone FP, Valvo ML (2011) Can the introduction of Xenopus laevis affect native amphibian populations? Reduction of reproductive occurrence in presence of the invasive species. Biol Invasions 13(7):1533-1541. https://doi.org/10.1007/s10530-010-9911-8

Lillo F, Dufresnes C, Faraone FP, Lo Valvo M, Stöck M (2013) Identification and potential origin of invasive clawed frogs Xenopus (Anura: Pipidae) in Sicily based on mitochondrial and nuclear DNA. Ital J Zool 80(4):566-573. https://doi.org/10.1080/11250003.2013.847502

Llewelyn J, Phillips BL, Alford RA, Schwarzkopf L, Shine R (2010) Locomotor performance in an invasive species: cane toads from the invasion front have greater endurance, but not speed, 
compared to conspecifics from a long-colonised area. Oecologia 162:343-348. https://doi.org/ $10.1007 / \mathrm{s} 00442-009-1471-1$

Lobos G, Jaksic FM (2005) The ongoing invasion of African clawed frogs (Xenopus laevis) in Chile: causes of concern. Biodivers Conserv 14(2):429-439. https://doi.org/10.1007/s10531004-6403-0

Lobos G, Measey GJ (2002) Invasive populations of Xenopus laevis (Daudin) in Chile. Herpetol J 12(4):163-168

Lobos G, Cattan P, Estades C, Jaksic FM (2013) Invasive African clawed frog Xenopus laevis in southern South America: key factors and predictions. Stud Neotropical Fauna Environ 48 (1):1-12. https://doi.org/10.1080/01650521.2012.746050

Lobos G, Mendez MA, Cattan P, Jaksic F (2014) Low genetic diversity of the successful invasive African clawed frog Xenopus laevis (Pipidae) in Chile. Stud Neotropical Fauna Environ 49 (1):50-60. https://doi.org/10.1080/01650521.2014.912865

Lombaert E, Guillemaud T, Cornuet J-M, Malausa T, Facon B, Estoup A (2010) Bridgehead effect in the worldwide invasion of the biocontrol Harlequin ladybird. PLoS One 5:e9743. https://doi. org/10.1371/journal.pone.0009743

Long JL (2003) Introduced mammals of the world: their history. Distribution and Influence. CSIRO Publishing. https://doi.org/10.1071/9780643090156

Louppe V, Courant J, Herrel A (2017) Differences in mobility at the range edge of an expanding invasive population of Xenopus laevis in the west of France. J Exp Biol 220:278-283. https:// doi.org/10.1242/jeb.146589

Louppe V, Courant J, Videlier M, Herrel A (2018) Differences in standard metabolic rate at the range edge versus the center of an expanding invasive population of Xenopus laevis in the West of France. J Zool 305:163-172. https://doi.org/10.1111/jzo.12548

Loveridge A (1959) Notes on the present herpetofauna of Ascension Island. Copeia 1959:69-70. https://doi.org/10.2307/1440104

Maciejewski K, Kerley GI (2014) Understanding tourists' preference for mammal species in private protected areas: is there a case for extralimital species for ecotourism? PLoS One 9(2):e88192. https://doi.org/10.1371/journal.pone.0088192

Mapondera TS, Burgess T, Matsuki M, Oberprieler RG (2012) Identification and molecular phylogenetics of the cryptic species of the Gonipterus scutellatus complex (Coleoptera: Curculionidae: Gonipterini). Aust J Entomol 51:175-188. https://doi.org/10.1111/j.14406055.2011.00853.x

Marabuto E (2014) The Afrotropical Miomantis caffra Saussure 1871 and Miomantis paykullii Stal 1871: first records of alien mantid species in Portugal and Europe, with an updated checklist of Mantodea in Portugal (Insecta: Mantodea). Biodiv Data J 2:e4117. https://doi.org/10.3897/BDJ. 2.e4117

Marion L (2013) Is the Sacred ibis a real threat to biodiversity? Long-term study of its diet in non-native areas compared to native areas. C R Biol 336(4):207-220. https://doi.org/10.1016/j. crvi.2013.05.001

Marko K, Verovnik R (2009) First record of Cacyreus marshalli (Lycaenidae) from the Balkan Peninsula. Nota Lepidopterologica 32(1):81-82

McCoid MJ, Fritts TH (1980a) Observations of feral populations of Xenopus laevis (Pipidae) in southern California. Bull South Calif Acad Sci 79(2):82-86. https://doi.org/10.2307/3671256

McCoid MJ, Fritts TH (1980b) Notes on the diet of a feral population of Xenopus laevis (Pipidae) in California. Southwest Nat 25(2):272-275. https://doi.org/10.2307/3671256

McCoid MJ, Fritts TH (1989) Growth and fat body cycles in feral populations of the African clawed frog, Xenopus laevis (Pipidae) in California with comments on reproduction. Southwest Nat 34 (4):499-505. https://doi.org/10.2307/3671508

McKinney M, Kark S (2017) Factors shaping avian alien species richness in Australia vs Europe. Divers Distrib 23(11):1334-1342. https://doi.org/10.1111/ddi.12625

Measey GJ (1998) Diet of feral Xenopus laevis (Daudin) in South Wales, UK. J Zool 246 (3):287-298. https://doi.org/10.1111/j.1469-7998.1998.tb00159.x 
Measey GJ (2001) Growth and ageing of feral Xenopus laevis (Daudin) in South Wales, UK. J Zool 254(4):547-555. https://doi.org/10.1017/S0952836901001054

Measey J (2016) Overland movement in African clawed frogs (Xenopus laevis): a systematic review. PeerJ 4:e2474. https://doi.org/10.7717/peerj.2474

Measey J (2017) Where do African clawed frogs come from? An analysis of trade in live Xenopus laevis imported into the USA. Salamandra 53(3):398-404

Measey GJ, Tinsley RC (1998) Feral Xenopus laevis in south Wales. Herpetol J 8:23-28. https:// doi.org/10.2307/1447816

Measey GJ, Rödder D, Green SL, Kobayashi R, Lillo F, Lobos G, Rebelo R, Thirion JM (2012) Ongoing invasions of the African clawed frog, Xenopus laevis: a global review. Biol Invasions 14(11):2255-2270. https://doi.org/10.1007/s10530-012-0227-8

Measey GJ, Vimercati G, De Villiers FA, Mokhatla MM, Davies SJ, Edwards S, Altwegg R (2015) Frog eat frog: exploring variables influencing anurophagy. PeerJ 3:e1204. https://doi.org/10. 7717/peerj.1204

Measey GJ, Vimercati G, de Villiers FA et al (2016) A global assessment of alien amphibian impacts in a formal framework. Divers Distrib 22:970-981. https://doi.org/10.1111/ddi.12462

Measey J, Davies SJ, Vimercati G, Rebelo A, Schmidt W, Turner A (2017) Invasive amphibians in southern Africa: a review of invasion pathways. Bothalia-African Biodivers Conserv 47 (2):1-12. https://doi.org/10.4102/abc.v47i2.2117

Measey J, Hui C, Somers M (2020) Terrestrial vertebrate invasions in South Africa. In: van Wilgen BW, Measey J, Richardson DM, Wilson JR, Zengeya TA (eds) Biological invasions in South Africa. Springer, Berlin, pp 113-150. https://doi.org/10.1007/978-3-030-32394-3_5

Meurisse N, Rassati D, Hurley BP, Brockerhoff EG, Haack RA (2018) Common pathways by which non-native forest insects move internationally and domestically. J Pest Sci 92:13-27. https://doi.org/10.1007/s10340-018-0990-0

Micevski N, Micevski B (2017) Cacyreus marshalli (Butler, 1898) (Lepidoptera: Lycaenidae) Confirmed for the Republic of Macedonia. Bull Nat Hist Mus Plovdiv 2(2017):17-20

Mikkola H (1996) Alien freshwater crustacean and indigenous mollusc species with aquaculture potential in eastern and southern Africa. South Afr J Aquat Sci 22:90-99. https://doi.org/10. $1080 / 10183469.1996 .9631375$

Moreau CS (2008) Unraveling the evolutionary history of the hyperdiverse ant genus Pheidole (Hymenoptera: Formicidae). Mol Phylogenet Evol 48(1):224-239. https://doi.org/10.1016/j. ympev.2008.02.020

Moreira FD, Marques R, Sousa M, Rebelo R (2017) Breeding in both lotic and lentic habitats explains the invasive potential of the African clawed frog (Xenopus laevis) in Portugal. Aquat Invasions 12(4). https://doi.org/10.3391/ai.2017.12.4.12

Moreno CA, Neill PE, Rozbaczylo N (2006) Native and non-indigenous boring polychaetes in Chile: a threat to native and commercial mollusc species. Rev Chil Hist 79:263-278. https://doi. org/10.4067/S0716-078X2006000200012

Müller GJ (1993) Black and brown widow spider bites in South Africa: a series of 45 cases. S Afr Med J 83(6):399-405

Na-Nakorn U, Brummett RE (2009) Use and exchange of aquatic genetic resources for food and aquaculture: Clarias catfish. Rev Aquac 1:214-223. https://doi.org/10.1111/j.1753-5131.2009. 01010.x

Norval G, Lu FY, Mao JJ, Slater K (2012) It is not inside, it is on top! An example of vehicularrafting by a house gecko (Hemidactylus frenatus Schlegel, 1836). Herpetol Notes 5:451-452

Nunes AL, Douthwaite RJ, Tyser B, Measey J, Weyl OLF (2016) Invasive crayfish threaten Okavango Delta. Front Ecol Environ 14:237-238. https://doi.org/10.1002/fee.1287

Nunes AL, Zengeya TA, Measey GJ, Weyl OLF (2017a) Freshwater crayfish invasions in South Africa: past, present and potential future. Afr J Aquat Sci 42:309-323. https://doi.org/ 10.2989/16085914.2017.1405788

Nunes AL, Zengeya TA, Hoffman AC, Measey GJ, Weyl OLF (2017b) Distribution and establishment of the alien Australian redclaw crayfish, Cherax quadricarinatus, in South Africa and Swaziland. PeerJ 5:e3135. https://doi.org/10.7717/peerj.3135 
Oliver WL (ed) (1993) Pigs, peccaries and hippos: status survey and conservation action plan. Island Press

Pepe (2017) The status of Pied Crow in south-western corner of Western Palearctic. http://callingbirds.com/2017/05/23/pied-crow/. Accessed on 10 Apr 2019

Peralta-García A, Valdez-Villavicencio JH, Galina-Tessaro P (2014) African clawed frog (Xenopus laevis) in Baja California: a confirmed population and possible ongoing invasion in Mexican watersheds. Southwest Nat 59(3):431-435. https://doi.org/10.1894/NBF-12.1

Pérez JE, Alfonsi C, Nirchio M, Barrios J (2006) The inbreeding paradox in invasive species. Interciencia 31:544-546

Philippart JCL, Ruwet JCL (1982) Ecology and distribution of tilapias. In: Pullin RSV, LoweMcConnell RH (eds) The biology and culture of tilapias. International Centre for Living Aquatic Resources Management (ICRAM) conference proceedings, vol 7, pp 15-60

Phillips BL, Brown GP, Shine R (2010) Life-history evolution in range-shifting populations. Ecology 91:1617-1627. https://doi.org/10.1890/09-0910.1

Picker M, Griffiths C (2011) Alien and invasive animals: a South African perspective. Penguin Random

Pignataro C, Vicidomini S, D'Alessandro C, Tarantino P (2006) Cacyreus marshalli (Butler) in Campania (Lepidoptera: Lycaenidae). Ann Mus Civ Rovereto Sez Arch St Sci Nat 22:205-212

Poole K (2010) Bird introductions. In: O'Connor TP, Sykes N (eds) Extinctions and invasions: a social history of British fauna. Windgather Press, Oxford, pp 155-165

Potgieter LJ, Douwes E, Gaertner M et al (2020) Biological invasions in South Africa's urban ecosystems: patterns, processes, impacts and management. In: van Wilgen BW, Measey J, Richardson DM, Wilson JR, Zengeya TA (eds) Biological invasions in South Africa. Springer, Berlin, pp 273-310. https://doi.org/10.1007/978-3-030-32394-3_11

Pullin RSV (1988) Tilapia genetic resources for aquaculture. In: Pullin RSV (ed) International Center for living aquatic resources management conference proceedings, Manilla, ICLARM

Pullin RS, Palmares ML, Casal CV, Dey MM, Pauly D (1997) Environmental impacts of tilapias. In: Fitzsimmons K (ed) Proceedings of the fourth international symposium on tilapia in aquaculture. Ithaca, NY, Northeast Regional Agricultural Engineering Service, pp 554-572

Pyšek P, Pergl J, van Kleunen M et al (2020) South Africa as a donor of naturalized and invasive plants to other parts of the world. In: van Wilgen BW, Measey J, Richardson DM, Wilson JR, Zengeya TA (eds) Biological invasions in South Africa. Springer, Berlin, pp 755-782. https:// doi.org/10.1007/978-3-030-32394-3_26

Quacchia A, Ferracini C, Bonelli S, Balletto E, Alma A (2008) Can the Geranium Bronze, Cacyreus marshalli, become a threat for European biodiversity? Biodivers Conserv 17(6):1429-1437

Raffaele HA (1989) The ecology of native and introduced granivorous birds in Puerto Rico. In: Woods CA, Sergile FE (eds) Biogeography of the West Indies: patterns and perspectives. CRC Press, Boca Raton, FL, pp 541-566. https://doi.org/10.1007/s10531-008-9350-3

Raidal SR, Riddoch PA (1997) A feather disease in Senegal doves (Streptopelia senegalensis) morphologically similar to psittacine beak and feather disease. Avian Pathol 26(4):829-836. https://doi.org/10.1080/03079459708419256

Ramsay GW (1990) Mantodea (Insecta), with a review of aspects of functional morphology and biology. Fauna N Z 19:1-96

Randrianandrianina FH, Racey PA, Jenkins RK (2010) Hunting and consumption of mammals and birds by people in urban areas of western Madagascar. Oryx 44:411-415. https://doi.org/10. 1017/S003060531000044X

Rebelo R, Amaral P, Bernardes M, Oliveira J, Pinheiro P, Leitão D (2010) Xenopus laevis (Daudin, 1802), a new exotic amphibian in Portugal. Biol Invasions 12(10):3383-3387. https://doi.org/ 10.1007/s10530-010-9757-0

Reino LM, Silva T (1998) The distribution and expansion of the Common Waxbill (Estrilda astrild) in the Iberian Peninsula. Biol Cons Fauna 102:163-167

Restrepo Betancur G, Varela Giraldo E, Usuga Suarez A (2016) Evaluación de la calidad espermática epididimal en hipopótamos Hippopotamus amphibius (Artiodactyla: Hippopotamidae) ubicados en el Magdalena Medio, Colombia. Acta Zool Mex 32 (2):158-167. https://doi.org/10.21829/azm.2016.322943 
Reynolds C, Miranda NA, Cumming GS (2015) The role of waterbirds in the dispersal of aquatic alien and invasive species. Divers Distrib 21(7):744-754. https://doi.org/10.1111/ddi.12334

Richardson DM, Thuiller W (2007) Home away from home-objective mapping of high-risk source areas for plant introductions. Divers Distrib 13(3):299-312. https://doi.org/10.1111/j. 1472-4642.2007.00337.x

Richardson DM, Pyšek P, Carlton JT (2011) A compendium of essential concepts and terminology in invasion ecology. In: Richardson DM (ed) Fifty years of invasion ecology: the legacy of Charles Elton. Wiley-Blackwell, Oxford, pp 409-420. https://doi.org/10.1002/9781444329988. $\operatorname{ch} 30$

Robinson TB, Peters K, Brooker B (2020) Coastal invasions: the South African context. In: van Wilgen BW, Measey J, Richardson DM, Wilson JR, Zengeya TA (eds) Biological invasions in South Africa. Springer, Berlin, pp 227-246. https://doi.org/10.1007/978-3-030-32394-3_9

Rödder D, Ihlow F, Courant J, Secondi J, Herrel A, Rebelo R, Measey GJ, Lillo F, de Villiers FA, De Busschere C, Backeljau T (2017) Global realized niche divergence in the African-clawed frog Xenopus laevis. Ecol Evol 7:1-15. https://doi.org/10.1002/ece3.3010

Roger F, Ratovonjato J, Vola P, Uilenberg G (2001) Ornithodoros porcinus ticks, bushpigs, and African swine fever in Madagascar. Exp Appl Acarol 25(3):263-269. https://doi.org/10.1023/ A:1010687502145

Rouget M, Robertson MP, Wilson JR et al (2016) Invasion debt-quantifying future biological invasions. Divers Distrib 22(4):445-456. https://doi.org/10.1111/ddi.12408

Roux J, Hurley BP, Wingfied MJ (2012) Diseases and pests of eucalypts, pines and wattle. In: Bredenkamp BV, Upfold SJ (eds) South African forestry handbook, 5th edn. South African Institute for Forestry, pp 303-336

Russell DJ, Thuesen PA, Thomson FE (2012) A review of the biology, ecology, distribution and control of Mozambique tilapia, Oreochromis mossambicus (Peters 1852) (Pisces: Cichlidae) with particular emphasis on invasive Australian populations. Rev Fish Biol Fish 22:533-554. https://doi.org/10.1007/s11160-011-9249-z

Sadchatheeswaran S, Branch GM, Robinson TB (2015) Changes in habitat complexity resulting from sequential invasions of a rocky shore: implications for community structure. Biol Invasions 17:1799-1816. https://doi.org/10.1007/s10530-014-0837-4

Saikia PJ, Gaswami VP (2017) Pied Crow Corvus albus at Jodhpur, India: Where did it come from? Indian Birds 13(6):147-149

Sanz-Aguilar A, Anadón JD, Edelaar P, Carrete M, Tella JL (2014) Can establishment success be determined through demographic parameters? A case study on five introduced bird species. PLoS One 9(10):e110019. https://doi.org/10.1371/journal.pone.0110019

Sarto i Monteys V (1992) Spread of the southern African lycaenid butterfly, Cacyreus marshalli Butler, 1898, (Lep.: Lycaenidae) in the Balearic Archipelago (Spain) and considerations on its likely introduction to continental Europe. J Res Lepidop 31(1/2):24-34

Schoeman AL, Kruger N, Secondi J et al (2019) Repeated reduction in parasite diversity in invasive populations of Xenopus laevis: a global experiment in enemy release. Biol Invasions. https://doi. org/10.1007/s10530-018-1902-1

Schofield PJ (2009) Geographic extent and chronology of the invasion of non-native lionfish (Pterois volitans [Linnaeus 1758] and P. miles [Bennett 1828]) in the Western North Atlantic and Caribbean Sea. Aquat Invasions 4:473-479. https://doi.org/10.3391/ai.2009.4.3.5

Schofield PJ (2010) Update on geographic extent and chronology of the invasion of non-native lionfish (Pterois volitans [Linnaeus 1758] and P. miles [Bennett 1828]) in the Western North Atlantic, Caribbean Sea and Gulf of Mexico. Aquat Invasions 4:473-479. https://doi.org/10. 3391/ai.2009.4.3.5

Seebens H, Blackburn TM, Dyer EE, Genovesi P, Hulme PE, Jeschke JM, Pagad S, Pyšek P, Winter M, Arianoutsou M, Bacher S (2017) No saturation in the accumulation of alien species worldwide. Nat Commun 8:14435. https://doi.org/10.1038/ncomms14435

Şekercioğlu ÇH (2013) Guineafowl, ticks and Crimean-Congo hemorrhagic fever in Turkey: the perfect storm? Trends Parasitol 29(1):1-2. https://doi.org/10.1016/j.pt.2012.10.001 
Shine R, Brown GP, Phillips BL (2011) An evolutionary process that assembles phenotypes through space rather than through time. Proc Natl Acad Sci U S A 108:5708-5711. https:// doi.org/10.1073/pnas.1018989108

Short KH, Petren K (2011) Multimodal dispersal during the range expansion of the tropical house gecko Hemidactylus mabouia. Ecol Evol 1(2):181-190. https://doi.org/10.1002/ece3.18

Short KH, Petren K (2012) Rapid species displacement during the invasion of Florida by the tropical house gecko Hemidactylus mabouia. Biol Invasions 14(6):1177-1186. https://doi.org/ 10.1007/s10530-011-0147-z

Simberloff D, Gibbons L (2004) Now you see them, now you don't!-population crashes of established introduced species. Biol Invasions 6(2):161-172. https://doi.org/10.1023/B:BINV. 0000022133.49752 .46

Simmons AD, Thomas CD (2004) Changes in dispersal during species' range expansions. Am Nat 164:378-395. https://doi.org/10.1086/423430

Simon CA, Worsfold TM, Lange L, Sterley J (2010) The genus Boccardia (Polychaeta: Spionidae) associated with mollusc shells on the south coast of South Africa. J Mar Biol Assoc U K 90:585-598. https://doi.org/10.1017/S0025315409990452

Skelton PH (2001) A complete guide to the freshwater fishes of southern Africa. Struik Publishers, Cape Town

Slingsby P (2017) Ants of Southern Africa: the ant book for all. Slingsby Maps

Smith KG, Fames DA (2012) History and current status of Egyptian goose (Alopochen aegyptiacus) in northwestern Arkansas. J Ark Acad Sci 66(1):200-204

Sousa M, Maurício A, Rebelo R (2018) The Xenopus laevis invasion in Portugal: an improbable connection of science, mediterranean climate and river neglect. In: Queiroz AI, Pooley S (eds) Histories of bioinvasions in the Mediterranean. Springer, Cham, pp 133-148. https://doi.org/10. 1007/978-3-319-74986-0_6

Souza RCCL, Fernandes FC, Silva EPA (2003) A study on the occurrence of the brown mussel Perna Perna on the Sambaquis of the Brazilian Coast. Rev do Museu de Arqueologia e Etnologia 13:3-24. https://doi.org/10.11606/issn.2448-1750.revmae.2003.109462

Spear D, Chown SL (2009) The extent and impacts of ungulate translocations: South Africa in a global context. Biol Conserv 142(2):353-363. https://doi.org/10.1016/j.biocon.2008.10.031

Stevens VM, Pavione S, Baguette M (2010) Variation within and between closely related species uncovers high intra-specific variability in dispersal. PLoS One 5:e11123. https://doi.org/10. 1371/journal.pone.0011123

Stiels D, Schidelko K, Engler JO, van den Elzen R, Rödder D (2011) Predicting the potential distribution of the invasive Common Waxbill Estrilda astrild (Passeriformes: Estrildidae). J Ornithol 152(3):769-780. https://doi.org/10.1007/s10336-011-0662-9

Strubbe D, Shwartz A, Chiron F (2011) Concerns regarding the scientific evidence informing impact risk assessment and management recommendations for invasive birds. Biol Conserv 144 (8):2112-2118. https://doi.org/10.1016/j.biocon.2011.05.001

Sutherland WJ, Allport G (1991) The distribution and ecology of naturalized Egyptian Geese Alopochen aegyptiacus in Britain. Bird Study 38(2):128-134. https://doi.org/10.1080/ 00063659109477080

Telford N, Channing A, Measey J (2019) Origin of invasive populations of the Guttural toad Sclerophrys gutturalis. Herpetol Conserv Biol 14(2):380-392

Tingley R, Romagosa CM, Kraus F, Bickford D, Phillips BL, Shine R (2010) The frog filter: amphibian introduction bias driven by taxonomy, body size and biogeography. Glob Ecol Biogeogr 19(4):496-503. https://doi.org/10.1111/j.1466-8238.2010.00530.x

Tolley KA, Burger M (2012) Chameleons of southern Africa. Penguin Random House South Africa

Tolley KA, Measey GJ (2007) Chameleons and vineyards in the Western Cape of South Africa: Is automated grape harvesting a threat to the Cape Dwarf Chameleon (Bradypodion pumilum)? Afr J Herpetol 56:85-89. https://doi.org/10.1080/21564574.2007.9635554

Tolley KA, Braae A, Cunningham M (2010) Phylogeography of the Clicking Stream Frog Strongylopus grayii (Anura, Pyxicephalidae) reveals cryptic divergence across climatic zones in an abundant and widespread taxon. Afr J Herpetol 59(1):17-32. https://doi.org/10.1080/ 04416651003744943 
Tomlinson ML, Field RA, Wheeler GN (2005) Xenopus as a model organism in developmental chemical genetic screens. Mol BioSyst 1(3):223-228. https://doi.org/10.1039/b506103b

Tompkins S (2015) Warthogs invade South Texas. Houston Chronicle Updated 9:19 pm CST, Wednesday, December 2, 2015. https://www.chron.com/sports/outdoors/article/Warthogsinvade-South-Texas-6671689.php. Accessed 29 Mar 2018

Tooke FGC (1955) The Eucalyptus snout beetle, Gonipterus scutellatus Gyll.: a study of its ecology and control by biological means, vol 3. Pretoria

Torchin ME, Mitchell CE (2004) Parasites, pathogens, and invasions by plants and animals. Front Ecol Environ 2:183-190. https://doi.org/10.1890/1540-9295(2004)002[0183:PPAIBP]2.0. $\mathrm{CO} ; 2$

Travis JMJ, Münkemüller T, Burton OJ (2010) Mutation and the evolution of dispersal during range expansions. J Evol Biol 23:2656-2667. https://doi.org/10.1111/j.1420-9101.2010.02123.x

Trewavas E (1983) Tilapiine fishes of the genera Sarotherodon, Oreochromis and Danakilia. British Museum of Natural History, London. https://doi.org/10.5962/bhl.title.123198

Valderrama Vásquez CA (2012) Wild hippos in Colombia. Aliens, The Invasive Species Bulletin, p 8

van den Audenaerde DEFT (1994) Introduction of aquatic species into Zambian waters, and their importance for aquaculture and fisheries. ALCOM Field Document No. 24. FAO, Harare, Zimbabwe. http://www.fao.org/docrep/005/AD005E/AD005E00.htm. Accessed 29 Mar 2018

van Sittert L, Measey GJ (2016) Historical perspectives on global exports and research of African clawed frogs (Xenopus laevis). Trans R Soc S Afr 71(2):157-166. https://doi.org/10.1080/ 0035919X.2016.1158747

van Wilgen BW (2020) A brief, selective history of researchers and research initiatives related to biological invasions in South Africa. In: van Wilgen BW, Measey J, Richardson DM, Wilson JR, Zengeya TA (eds) Biological invasions in South Africa. Springer, Berlin, pp 31-64. https:// doi.org/10.1007/978-3-030-32394-3_2

van Wilgen NJ, Gillespie MS, Richardson DM, Measey J (2018) A taxonomically and geographically constrained information base limits non-native reptile and amphibian risk assessment: a systematic review. PeerJ 6:5850. https://doi.org/10.7717/peerj.5850

van Wilgen BW, Measey J, Richardson DM, Wilson JR, Zengeya T (2020) Biological invasions in South Africa: an overview. In: van Wilgen BW, Measey J, Richardson DM, Wilson JR, van Wilgen BW (eds) Biological invasions in South Africa. Springer, Berlin, pp 3-30. https://doi. org/10.1007/978-3-030-32394-3_1

Vercammen P, Seydack AH, Oliver WL (1993) The bush pigs (Potamochoerus porcus and P. larvatus). In: Oliver WL (ed) Pigs, peccaries and hippos. IUCN, Gland, pp 93-100

Vetter RS, Vincent LS, Itnyre AA, Clarke DE, Reinker KI, Danielsen DW, Robinson LJ, Kabashima JN, Rust MK (2012a) Predators and parasitoids of egg sacs of the widow spiders, Latrodectus geometricus and Latrodectus hesperus (Araneae: Theridiidae) in southern California. J Arachnol 40(2):209-215. https://doi.org/10.1636/Hi11-93.1

Vetter RS, Vincent LS, Danielsen DW, Reinker KI, Clarke DE, Itnyre AA, Kabashima JN, Rust MK (2012b) The prevalence of brown widow and black widow spiders (Araneae: Theridiidae) in urban southern California. J Med Entomol 49(4):947-951. https://doi.org/10.1603/ME11285

Vitule JRS, Umbria SC, Aranha JMR (2006) Introduction of the African catfish Clarias gariepinus (Burchell, 1822) into Southern Brazil. Biol Invasions 8:677-681. https://doi.org/10.1007/ s10530-005-2535-8

Walker LM (2014) A revision of the Polydora-complex (Annelida: Spionidae) fauna of Australia. $\mathrm{PhD}$ thesis, University of Queensland, St Lucia QLD

Wang S, Hong Y, Measey J (2019) An established population of African clawed frogs (Xenopus laevis) in mainland China. BioInvasions Rec 8(2):457-464. https://doi.org/10.3391/bir.2019.8. 2.29

Welcomme RL (1988) International introductions of inland aquatic species. FAO Fisheries Technical Paper No 294, $318 \mathrm{p}$

Welz A (2017) How aquaculture is threatening the native fish species of Africa. Yale Environment 360. https://e360.yale.edu/features/how-aquaculture-is-threatening-the-native-fish-species-ofafrica. Accessed 29 Mar 2018 
Weterings R, Vetter KC (2017) Invasive house geckos (Hemidactylus spp.): their current, potential and future distribution. Curr Zool 64(5):559-573. https://doi.org/10.1093/cz/zox052

Wetmore A, Swales BH (1931) The birds of Haiti and the Dominican Republic. U.S. Mus Nat Hist Bull 155:1-459. https://doi.org/10.5479/si.03629236.155.i

Wetterer JK (2012) Worldwide spread of the African big-headed ant, Pheidole megacephala (Hymenoptera: Formicidae). Myrmecol News 17:51-62

Weyl OL, Daga VS, Ellender BR, Vitule JR (2016) A review of Clarias gariepinus invasions in Brazil and South Africa. J Fish Biol 89:386-402. https://doi.org/10.1111/jfb.12958

Weyl OLF, Ellender BR, Ivey P, Jackson MC, Tweddle D, Wassermann RJ, Woodford DJ, Zengeya TA (2017) Africa: brown trout introductions, establishment, current status, impacts and conflicts. In: Lobón-Cerviá J, Sanz N (eds) Brown trout: biology, ecology and management. Wiley-Blackwell, pp 623-639. https://doi.org/10.1002/9781119268352.ch24

Weyl OLF, Ellender B, Wassermann RJ et al (2020) Alien freshwater fauna in South Africa. In: van Wilgen BW, Measey J, Richardson DM, Wilson JR, Zengeya TA (eds) Biological invasions in South Africa. Springer, Berlin, pp 151-182. https://doi.org/10.1007/978-3-030-32394-3_6

Wheeler WM (1922) The ants collected by the American Museum Congo Expedition. Bull Am Mus Nat Hist 45:39-269

Wiley JW (1985) Shiny Cowbird parasitism in two avian communities in Puerto Rico. Condor 87 (2):165-176. https://doi.org/10.2307/1366878

Wilson JRU, Dormontt EE, Prentis PJ, Lowe AJ, Richardson DM (2009) Something in the way you move: dispersal pathways affect invasion success. Trends Ecol Evol 24:136-144. https://doi. org/10.1016/j.tree.2008.10.007

Wilson JR, Foxcroft LC, Geerts S et al (2020) The role of environmental factors in promoting and limiting biological invasions in South Africa. In: van Wilgen BW, Measey J, Richardson DM, Wilson JR, Zengeya TA (eds) Biological invasions in South Africa. Springer, Berlin, pp 353-384. https://doi.org/10.1007/978-3-030-32394-3_13

WRiMS (2019) World register of introduced marine species. www.marinespecies.org/introduced/. Accessed 29 Mar 2018

Yesou P, Clergeau P (2005) Sacred Ibis: a new invasive species in Europe. Birding World 18 (12):517-526

Open Access This chapter is licensed under the terms of the Creative Commons Attribution 4.0 International License (http://creativecommons.org/licenses/by/4.0/), which permits use, sharing, adaptation, distribution and reproduction in any medium or format, as long as you give appropriate credit to the original author(s) and the source, provide a link to the Creative Commons licence and indicate if changes were made.

The images or other third party material in this chapter are included in the chapter's Creative Commons licence, unless indicated otherwise in a credit line to the material. If material is not included in the chapter's Creative Commons licence and your intended use is not permitted by statutory regulation or exceeds the permitted use, you will need to obtain permission directly from the copyright holder.

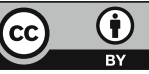

